\title{
Microbial processes in the weathering crust aquifer of a temperate glacier
}

\author{
Brent C. Christner ${ }^{1,2}$, Heather F. Lavender ${ }^{2}$, Christina L. Davis ${ }^{1}$, Erin E. Oliver ${ }^{2, a}$, Sarah U. Neuhaus ${ }^{3}$, \\ Krista F. Myers ${ }^{4}$, Birgit Hagedorn ${ }^{5}$, Slawek M. Tulaczyk ${ }^{3}$, Peter T. Doran ${ }^{4}$, and William C. Stone ${ }^{6}$ \\ ${ }^{1}$ Department of Microbiology and Cell Science, University of Florida, Biodiversity Institute, Gainesville, FL 32611, USA \\ ${ }^{2}$ Department of Biological Sciences, Louisiana State University, Baton Rouge, LA 70803, USA \\ ${ }^{3}$ Department of Earth and Planetary Sciences, University of California Santa Cruz, Santa Cruz, CA 95064, USA \\ ${ }^{4}$ Department of Geology and Geophysics, Louisiana State University, Baton Rouge, LA 70803, USA \\ ${ }^{5}$ Sustainable Earth Research LLC, Anchorage, AK 99508, USA \\ ${ }^{6}$ Stone Aerospace, Del Valle, TX 78617, USA \\ ${ }^{a}$ current address: Department of Biology, San Diego State University, San Diego, CA 92182, USA
}

Correspondence: Brent C. Christner (xner@ufl.edu)

Received: 2 July 2018 - Discussion started: 8 August 2018

Revised: 29 October 2018 - Accepted: 3 November 2018 - Published: 26 November 2018

\begin{abstract}
Incident solar radiation absorbed within the ablation zone of glaciers generates a shallow perched aquifer and seasonal icebound microbial habitat. During the melt seasons of 2014 and 2015, borehole investigations were used to examine the physical, geochemical, and microbiological properties in the near-surface ice and aquifer of the temperate Matanuska Glacier (south-central Alaska). Based on temperature, solar forcing, and ice optical properties, the dissipation of shortwave radiation promoted internal melting and the formation of a weathering crust with a maximum depth of $\sim 2 \mathrm{~m}$. Boreholes into the weathering crust provided access to water percolating through the porous ice. The water had low ion concentrations $\left(4-12 \mu \mathrm{S} \mathrm{cm}^{-1}\right)$, was aerobic (12 $\mathrm{mg} \mathrm{O}_{2} \mathrm{~L}^{-1}$ ), contained 200 to 8300 cells $\mathrm{mL}^{-1}$, and harbored growing populations with estimated in situ generation times of 11 to 14 days. During the melt season, the upper $2 \mathrm{~m}$ of ice experienced at least $3 \%$ of the surface photosynthetically active radiation flux and possessed a fractional water content as high as $10 \%$. Photosynthetic subsistence of biogeochemical reactions in the weathering crust ecosystem was supported by ex situ metabolic experiments and the presence of phototrophic taxa (cyanobacteria, golden and green algae) in the aquifer samples. Meltwater durations of $\sim 7.5$ months coupled with the growth estimates imply biomass may increase by 4 orders of magnitude each year. Our results provide insight into how seasonal dynamics affect habitability
\end{abstract}

of near-surface ice and microbial processes in a portion of the glacial biome poised to expand in extent with increasing global temperature and ablation season duration.

\section{Introduction}

Annual melt cycles generate water on the surfaces of glaciers and ice sheets that is transported through a sinuous network of channels to the margin as supraglacial runoff or glacier bed via crevasses and moulins to be discharged subglacially (Smith et al., 2015; Chu, 2014). Meltwater can also be temporarily stored on the surface in cryoconite holes (Hodson et al., 2008; Edwards and Cameron, 2017), supraglacial lakes (Fitzpatrick et al., 2014; Langley et al., 2016), and nearsurface aquifers within the ice (Hoffman et al., 2014; Karlstrom et al., 2014; Cook et al., 2016). The low-density, highly porous surface ice prevalent in ablation zones serves as a reservoir for meltwater, affecting the timing and magnitude of its delivery to supraglacial, subglacial, and proglacial systems (Munro, 2011; Smith et al., 2017; Cooper et al., 2018; Stevens et al., 2018). As such, ice mass loss driven by warming temperatures has motivated numerous efforts to understand how surface meltwater production, storage, and hydrology will affect future sea level rise (e.g., Bamber and Aspinall, 2013) and subglacial hydrological processes that 
influence ice velocity and ice sheet thinning (Zwally et al., 2002; Sole et al., 2011).

Glacial meltwater production also provides aquatic environments that are suitable for supporting microbial communities and promoting active biogeochemical cycling on glacier surfaces (Hodson et al., 2008; Edwards and Cameron, 2017). Conditions in certain supraglacial environments even fall within the tolerances of cold-adapted multicellular organisms, and invertebrate populations have been documented in a number of cryoconite ecosystems (Zawierucha et al., 2015). The uptake of nutrients and dissolved organic carbon in fast-flowing supraglacial streams demonstrates the effect of microbial activity on meltwater composition and implies that higher degrees of biogeochemical processing are possible with longer hydrologic retention times (Scott et al., 2010). Visual discoloration of snow and ice surfaces due to blooms of cyanobacteria and algae are commonly observed (Hopes et al., 2017), and in regions with standing water (e.g., cryoconite holes), photosynthetic rates can be sufficient for positive net community productivity (Anesio et al., 2009; Hodson et al., 2013). An important consequence of microbial growth and pigment production is darkening of the ice surface and albedo reduction (Yallop et al., 2012; Stibal et al., 2017; Tedstone et al., 2017), a critical parameter governing surface melting (Gardner and Sharp, 2010).

In the ablation zone, the absorption of shortwave radiation within the ice promotes internal melting and density reduction (LaChapelle, 1959; Munro, 1990), forming a highly porous veneer on the glacier surface termed the weathering crust (Müller and Keeler, 1969). Flow paths through the weathering crust's saturated water table link segments of the supraglacial hydrological system, transporting microbes and nutrients via subsurface flow (Irvine-Fynn et al., 2012; Hoffman et al., 2014; Karlstrom et al., 2014; Cook et al., 2016). The availability of photosynthetically active radiation (PAR) in the near-surface aquifer may support phototrophic metabolism (Hodson et al., 2013; Irvine-Fynn and Edwards, 2014), allowing the development of microbial communities in the glacial weathering crust during the melt season. The weathering crust aquifer (WCA) is presumed to be an important component of the hydrological and biogeochemical budget for cold-based glaciers (Irvine-Fynn et al., 2012; Cook et al., 2016; Rassner et al., 2016), but no data have been available to assess microbial activities and biogeochemical transformations in temperate ice systems.

This study examined physical, geochemical, and microbiological properties in the weathering crust of the temperate Matanuska Glacier (located in the Chugach Mountains of south-central Alaska) to gain information on the nature of the near-surface aquatic ecosystem it supports during the ablation season. Comparison of water percolating through the weathering crust to the surface ice melt revealed unique geochemical features and the enrichment of certain microbial taxa in the WCA, supporting that it may possess distinct biogeochemical processes and species within the supraglacial environment. Sufficient PAR fluxes exist with depth in the ice for photosynthetic activity, and the WCA samples contained growing cell populations and phototrophic taxa. We use these biogeochemical data and modeling results to speculate on how microbial processes in the weathering crust are likely affected by seasonal variability in temperature, light, and water availability.

\section{Methods}

\subsection{Site description}

The Matanuska Glacier is a $\sim 48 \mathrm{~km}$ valley glacier with an upper accumulation zone at an elevation of $\sim 3500 \mathrm{~m}$ a.s.l. and the terminus is at $\sim 500 \mathrm{~m}$ a.s.l.; its width ranges from $\sim 3 \mathrm{~km}$ near the equilibrium line to $\sim 5 \mathrm{~km}$ along the terminus (Arcone et al., 1995). The measurements and samples analyzed in this study were collected in the vicinity of a research site established on the western lateral margin in the ablation zone of the glacier $\left(61^{\circ} 42^{\prime} 9.3^{\prime \prime} \mathrm{N}, 147^{\circ} 37^{\prime} 23.2^{\prime \prime} \mathrm{W}\right)$ during June to July of 2014 and 2015, approximately $8 \mathrm{~km}$ from the glacier terminus. Science and technical operations were performed on the ice surface and in portable shelters that contained various scientific equipment, including a $61 \times 31 \mathrm{~cm}$ laminar flow hood (Fungi Perfecti LLC, item no. E-ALFH1). A meltwater stream $\sim 100 \mathrm{~m}$ up-glacier from the research camp was sampled to provide a measure of the microbial community structure in supraglacial water environments in proximity to the study site.

\subsection{Borehole sampling of ice and water}

Boreholes were melted into the ice surface using three different approaches. First, water heated using a diesel-fueled water heater (Pressure-Pro Inc.) was circulated through a tapered aluminum melt head ( 10 or $30 \mathrm{~cm}$ in diameter; $30 \mathrm{~cm}$ in length) that was attached to a standard garden hose and manually guided while descending through the ice. Secondly, an electrically heated copper melt head of $10 \mathrm{~cm}$ was used to create boreholes of up to $8.5 \mathrm{~m}$ in depth. The electrothermal heater was powered with a portable $2.5 \mathrm{~kW}$ generator, with the primary front heater reaching up to $2 \mathrm{~kW}$ in power output and enabling ice penetration rates of $1-2 \mathrm{~m} \mathrm{~h}^{-1}$. Finally, 25 to $30 \mathrm{~cm}$ boreholes were generated with a laser-powered ice-penetrating cryobot that heated the water and used onvehicle hot water jets to melt the ice and control its direction and rate of descent (Stone et al., 2014, 2018). In June 2014, four $30 \mathrm{~cm}$ diameter boreholes (BH1-3 and BH-5; 4 to $30 \mathrm{~m}$ in depth) and one $10 \mathrm{~cm}$ diameter borehole (BH4; $4 \mathrm{~m}$ in depth) were used to sample ice and water in the WCA (Table S1 in the Supplement). The same location on the glacier was revisited from June to July 2015, and two $30 \mathrm{~cm}$ diameter boreholes (BH6 and $\mathrm{BH} 7 ; 1.4-15.4 \mathrm{~m}$ in depth) and three $10 \mathrm{~cm}$ diameter boreholes (BH8-10; 4 to $5 \mathrm{~m}$ in depth) were sampled (Table S1). 
In the $30 \mathrm{~cm}$ diameter boreholes, particulates in large volumes of meltwater (up to $404 \mathrm{~L}$ ) were size fractionated (i.e., particulate fractions $>3 \mu \mathrm{m},<3$ to $>0.8 \mu \mathrm{m}$, and $<0.8$ to $>0.2 \mu \mathrm{m})$ and concentrated in situ on $142 \mathrm{~mm}$ Supor PES membranes (Pall) using a McLane large-volume water transfer system (WTS-LV; Christner et al., 2014). Water in the boreholes was also sampled by lowering clean silicone tubing into the borehole and using a peristaltic pump to deliver the water to the surface. To determine if the ice was porous and active water flow was occurring through the weathering crust, water was drained from several of the boreholes and monitored daily to assure that meltwater was not entering directly from the surface. Two of the drained boreholes refilled with water that percolated laterally from the WCA (BH4 and BH10; Table S1), and each was subsequently monitored at approximately hourly intervals when personnel were on site (typically 09:00 to 18:00 local time). The borehole water was retrieved at the surface using sterilized tubing and a peristaltic pump or by lowering clean acid-washed HDPE bottles into the borehole using nylon paracord (Fig. S1 in the Supplement).

Meltwater samples from discrete ice depth intervals were obtained using a customized water sampler and filtration system that was integrated as a scientific payload on the cryobot (Clark et al., 2017; Stone et al., 2018). Operation of the cryobot requires a water-filled cavity; therefore, the $30 \mathrm{~cm}$ aluminum melt head was used to create a $\sim 1 \mathrm{~m}$ pilot hole, the meltwater generated was replaced with an equal volume from a supraglacial stream, and this water was continually circulated through a $0.2 \mu \mathrm{m}$ filter for $\sim 1 \mathrm{~h}$ to reduce the number of microorganisms in the priming water. Stainless steel Swagelok fittings and tubing from the melt head were connected to a peristaltic pump, which was used to pump water into sterile $120 \mathrm{~mL}$ capacity sampling bags (Labtainer ${ }^{\mathrm{TM}}$ BioProcess Container, cat. no. SH30658.12; 10 total per mission) or through $90 \mathrm{~mm}$ Supor PES filters with a $0.2 \mu \mathrm{m}$ pore size (five total per mission). The sampling bags had duel ports: one for filling through a sanitary check valve and one for overflow, which was controlled by a sanitary pressure relief valve. The filters were housed within a Savillex filter holder made of PFA fluoropolymer and sealed with ULTEM clamps. During water or filtration sampling, the cryobot was operated in "passive" mode (i.e., the hot water jets were not used and heat transfer was directed only to the melt head of the vehicle; Clark et al., 2017), which melted the ice at a rate of $\sim 1 \mathrm{~L} \mathrm{~min}^{-1}$. To prevent inadvertent collection of bulk borehole water, the sampling pumps were operated at a rate of $56 \mathrm{~mL} \mathrm{~min}^{-1}$ (i.e., $\sim 6 \%$ of the rate of meltwater generation). Based on the rate of descent and collection, each water sample of $120 \mathrm{~mL}$ represented the melt generated from a depth horizon of approximately $1.6 \mathrm{~cm}$ in the ice.

\subsection{Conductivity, $\mathrm{pH}$, and chemical composition of the water samples}

Electrical conductivity and $\mathrm{pH}$ of the water samples were measured using a multiparameter PCS test probe (Oakton Instruments, Vernon Hills, IL).

The concentration of major ions and trace elements in the water samples were analyzed using inductively coupled plasma mass spectrometry with a reaction cell for cations (ICP RC-MS, Agilent 7500c) and ion chromatograph (Dionex ICS 5000+) for anions. For ICP RC-MS analysis, samples were acidified to $1 \% \mathrm{HNO}_{3} v / v$ and analyzed for 28 elements. Elements prone to interferences (e.g., $\mathrm{Ca}^{2+}$ and $\mathrm{As}^{3+}$ ) were analyzed using $\mathrm{H}_{2}$ and $\mathrm{He}$ as the reaction gas. Quantification was performed using seven external calibration standards ranging from 0.1 to $100 \mathrm{ppb}$. Drift correction was achieved by online addition of $10 \mathrm{ppb}$ of a four element internal standard mix $(\operatorname{Li}(7), Y, C e$, and $\mathrm{Bi})$. An IonPac AS15 $2 \times 250 \mathrm{~mm}$ column was used for anion separation using $38 \mathrm{mM} \mathrm{KOH}$ as eluent and an ASRS 300 zero reagent suppressor. The sample injection volume was $10 \mu \mathrm{L}$ and quantification was performed using five external calibration standards ranging from 0 to $10 \mathrm{ppm}$. Calibration verification standards and blanks were run every 10th analysis for anions and cations. The NIST SRM 1643d was used to verify cation calibration and a secondary anion standard (Dionex Anion Standard II) was used to check anion calibration. Samples that exceeded the calibration by $120 \%$ were diluted and reanalyzed. Nitrite was not analyzed due to overlap with bicarbonate in the chromatogram. The mass balance deficit between anions and cations was used to determine bicarbonate concentrations.

\subsection{Ice temperature and meltwater content}

Vertical gradients of temperature in the ice surface were measured over 2 months during the summer of 2015 by deploying a sensor string into a borehole with thermistor sensors placed at every $10 \mathrm{~m}$ along the string and collecting data at hourly intervals. The thermistors were calibrated under controlled conditions and had an accuracy of ca. $0.1^{\circ} \mathrm{C}$.

A one-dimensional finite-difference model utilizing the explicit Euler central difference method (Lim and Jørgensen, 2006) was used to calculate ice temperatures within $100 \mathrm{~m}$ of the surface at $0.25 \mathrm{~m}$ vertical intervals and with an hourly time step. Since Matanuska Glacier is temperate, the lower boundary condition was set to the pressure-melting point while the surface condition was driven using the $2 \mathrm{~m}$ air temperature and the surface downwelling shortwave flux in air. Because these quantities are not available from nearby weather stations, the European Centre for Medium-Range Weather Forecasts ERA-Interim reanalysis data for the 0.75 by $0.75^{\circ}$ cell containing this region of the Matanuska Glacier for the period between the beginning of 2014 and the end of 2016 were used (Fig. 1b; Dee et al., 2011). Air temperature is 

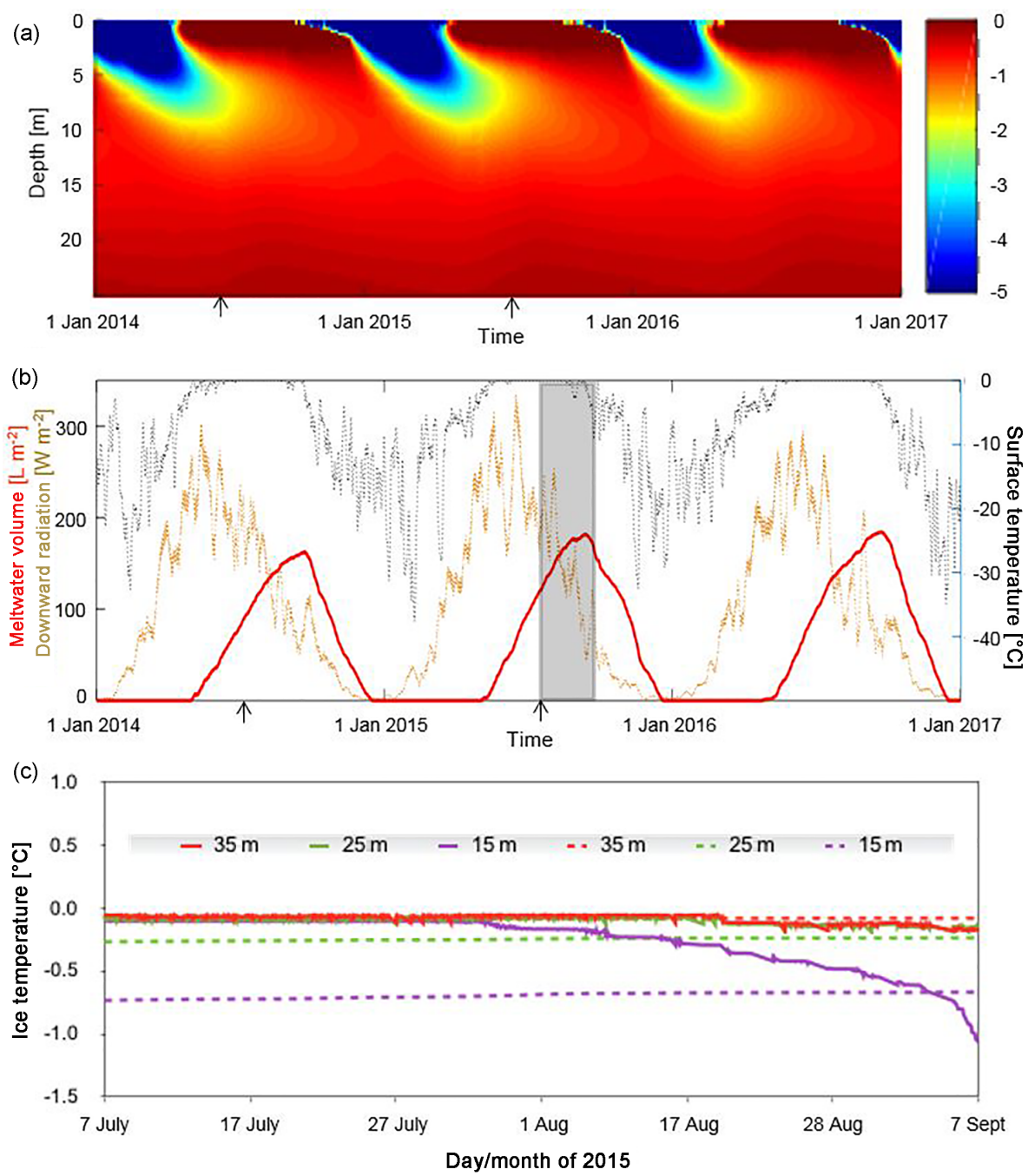

Figure 1. Temperature and ice water content from 2014 to 2016. (a) Modeled ice temperature was calculated using a finite-difference solver to a one-dimensional diffusion-advection-production equation. Only values between 0 (red limit) and $-5^{\circ} \mathrm{C}$ (blue limit) are plotted. (b) The model is driven by the ERA-Interim reanalysis $2 \mathrm{~m}$ air temperature (black dots) and downward radiation data (brown dots) for the region (Dee et al., 2011). Both forcings are plotted at hourly intervals after smoothing with a daily (surface temperature) and weekly (radiation) runningaverage filter to suppress short-term variability. The grey region in panel (b) represents the summer 2015 interval plotted in panel (c) when ice temperature data were collected. The arrows in panels (a) and (b) indicate the timing of the two field campaigns. (c) Comparison among ice temperatures observed with thermistors placed in a borehole at 15, 25, and $35 \mathrm{~m}$ below the surface from early July to early September of 2015 (solid lines) and the simulated ice temperatures (dashed lines) for the same depths below the surface of the model domain.

taken to be equal to the surface temperature at the top of the model domain when the former is negative but is set to the melting point of ice when air temperature is positive. When the latter is the case, the surface melt rate was calculated using the positive-degree-day parametrization (van Beusekom et al., 2010) and a melt factor of $5 \mathrm{~mm}^{\circ} \mathrm{C}^{-1}$ day $^{-1}$. The surface melt rate, which typically reaches several centimeters per day in summer (Ensminger et al., 1999; Reynolds, 2005; Mankoff and Russo, 2013), was treated throughout the $100 \mathrm{~m}$ thick model domain as spatially uniform upward advection. Surface solar radiation downwards from the ERA-Interim dataset was used to scale internal heating in the upper op- tically translucent part of the glacier following the exponential Lambert law of light attenuation with an $e$-folding length scale of $0.825 \mathrm{~m}$ as constrained by the PAR data (Fig. 2a). When ice is at $0^{\circ} \mathrm{C}$ and still experiencing internal heating from solar radiation, the additional heat is used to calculate meltwater fraction using the latent heat of ice fusion $\left(334000 \mathrm{~J} \mathrm{~kg}^{-1}\right)$. Similarly, when wet ice is cooling down, the negative heat budget is used to first freeze the internal meltwater, and ice temperature can drop below $0{ }^{\circ} \mathrm{C}$ only when its internal water content reaches zero. Heat conduction was treated as a diffusive process using a diffusion coefficient of $1.2 \times 10^{-6} \mathrm{~m}^{2} \mathrm{~s}^{-1}$. The model neglects the impact of sea- 

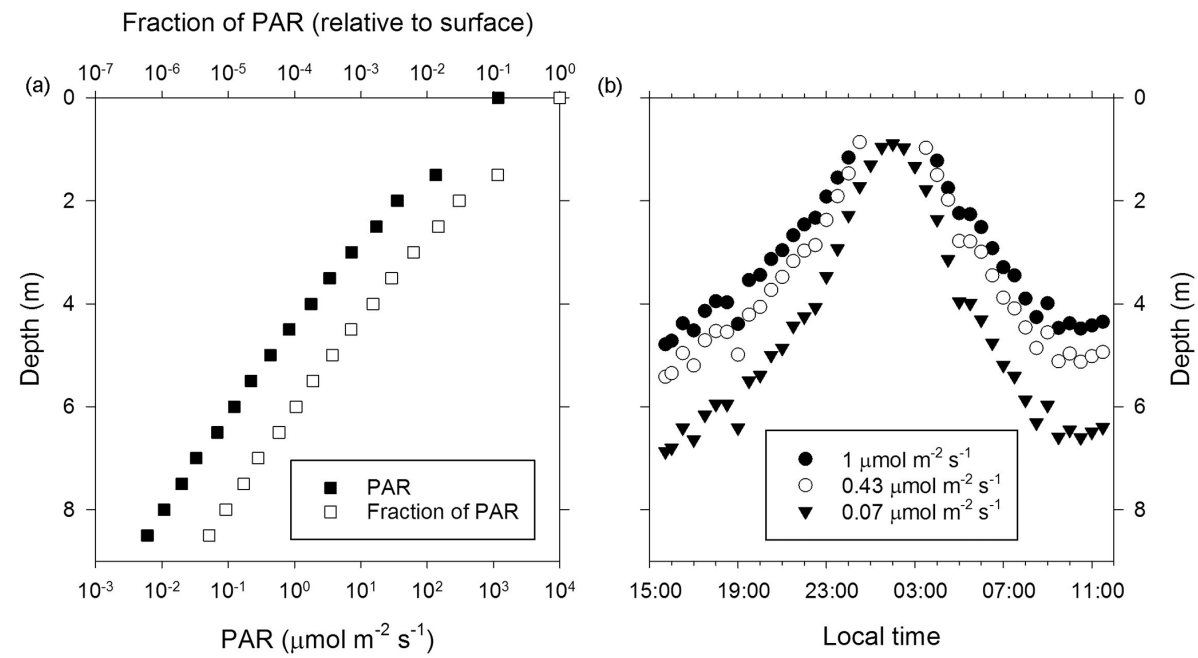

Figure 2. PAR optical properties of the near-surface ice during the 2014 ablation season. (a) Measurement of PAR attenuation to a depth of $8.5 \mathrm{~m}$. (b) Diel pattern for select PAR fluxes that support oxygenic photosynthesis in cold and shaded aquatic environments (Priscu et al., 1988; Hawes and Schwarz, 2001). The data plotted were derived from an overnight measurement with the sensor at a depth of $3.5 \mathrm{~m}$ and then using data from panel (a) to extend the overnight profile to the upper $8.5 \mathrm{~m}$ of the ice column.

sonal snowpack on either the temperature or energy balance of the simulated glacier surface. In winter, such snowpack would slow cooling of underlying glacier ice while in early summer it would hinder light penetration into the glacier near the surface. The entire model domain was initialized as temperate ice and then the calculation cycled through repeats of the 3-year surface forcings until the drift of calculated ice temperatures reached $<0.01^{\circ} \mathrm{C}$ over a 3 -year cycle.

\subsection{Determination of the PAR fluence rate}

PAR $(400-700 \mathrm{~nm})$ was measured in boreholes using a LICOR LI-193 spherical underwater quantum sensor (LI-COR, Inc) and $10 \mathrm{~m}$ of underwater cable. The stated sensitivity of the LI-193 is typically $7 \mu \mathrm{A}$ per $1000 \mu \mathrm{mol} \mathrm{s}^{-1} \mathrm{~m}^{-2}$ in water. PAR was also measured at the ice surface with a LI-COR quantum sensor mounted on a small board using a leveling device. Both sensors were driven and logged by a LI-COR LI-1400 data logger and were calibrated prior to the first field season.

Two types of measurements were made in water-filled boreholes: vertical profiling within a short period of time and overnight measurement at a fixed depth. For profiling, the sensor was deployed in a $10 \mathrm{~cm}$ diameter borehole and measurements were taken from 0 to $8.5 \mathrm{~m}$ at $0.5 \mathrm{~m}$ increments. To mitigate the "borehole effect" caused when measuring transmitted light in a liquid-filled borehole, the sensor was placed $1 \mathrm{~m}$ below a $10-15 \mathrm{~cm}$ opaque packer (Muni-Ball ${ }^{\circledR}$, Cherne Industries Inc.) that was inflated at discrete depths to create a lighttight seal. To avoid freezing the packer in the ice during overnight deployments, the sensor was deployed at $3.5 \mathrm{~m}$ in a $30 \mathrm{~cm}$ diameter borehole and light was blocked from entering with an opaque tarp. Due to the larger distance between blocked light and the sensor, the diel measurement may have been subject to a larger borehole effect than the profile measurement.

The PAR attenuation coefficient was derived as described by Hodson et al. (2013) based on $\operatorname{PAR}(Z)=\operatorname{PAR}_{0} e^{-K Z}$, where $Z$ is the ice depth from the surface in meters, PAR $_{0}$ is the surface PAR flux in $\mu \mathrm{mol} \mathrm{m}{ }^{-2} \mathrm{~s}^{-1}$, and $K$ is the PAR attenuation coefficient.

\subsection{Epifluorescence microscopy}

The water samples collected for epifluorescence microscopic analysis were immediately fixed by addition of sodium borate-buffered formalin ( $5 \%$ final concentration), stored at $\sim 4{ }^{\circ} \mathrm{C}$, and analyzed within 1 month of collection. Cells were concentrated by filtering 10 to $40 \mathrm{~mL}$ of sample onto $0.22 \mu \mathrm{m}$ black Isopore filters (Millipore, cat. no. GTBP02500) and stained for $15 \mathrm{~min}$ in the dark with SYBR $^{\mathrm{TM}}$ Gold (Molecular Probes Inc., cat. no. S-11494) buffered in Tris-borate-EDTA (pH 8.3). The staining solution was pulled through the filter by applying vacuum, the filter was mounted on a microscope slide, and a drop of antifade $(0.1 \%$ phenylenediamine in a $1: 1$ ratio of phosphatebuffered saline and glycerol) was added to the middle of the filter before applying a coverslip. For each sample, the number of DNA-containing cells in 60 fields of view (FOVs) was enumerated using an Olympus BX51 epifluorescence microscope. The cell concentration was estimated by calculating the average number of cells per FOV, multiplying by the number of FOVs per filter, and dividing by the volume of the sample filtered. 


\subsection{Determination of ATP biomass}

Triplicate measurements of ATP were performed on each sample in the field by concentrating the cells in $25 \mathrm{~mL}$ of water on a $0.22 \mu \mathrm{m}$ Millex-GS syringe filter (Millipore, cat. no. SLG033SS), followed by passing $0.2 \mathrm{~mL}$ of Extractant $\mathrm{B} / \mathrm{S}$ from the ATP Biomass Kit HS (BioThema Inc., cat. no. 266-112) and collecting the filtrate. For each procedural replicate, one-quarter of the filtrate $(50 \mu \mathrm{L})$ was added to $400 \mu \mathrm{L}$ of ATP Reagent HS and luminescence was measured using a 20/20n luminometer (Turner BioSystems, cat. no. E5331). Subsequently, 1 pmol of an ATP standard was added to each sample and luminescence was measured, allowing the relative luminescence units (RLUs) for each measurement to be corrected for possible inhibition of the luciferase enzyme and/or changes of ambient temperature during the course of measurement. The quantity of ATP was determined by generating standard curves (six 10-fold dilutions of $100 \mathrm{nM}$ to $1 \mathrm{pM}$ ATP) that allowed relating RLUs to the ATP concentration.

\subsection{Detection of respiring cells via reduction of a tetrazolium salt}

An assay with the tetrazolium salt XTT [2,3-Bis(2-methoxy4-nitro-5-sulfophenyl)-2H-tetrazolium-5-carbox-anilide] was performed in the field to assess cellular respiration activity. The water sample $(50 \mathrm{~L})$ was filtered through a $142 \mathrm{~mm}, 0.22 \mu \mathrm{m}$ SUPOR filter (Pall) and the retentate was suspended in a volume of filtrate that concentrated material $>0.2 \mu \mathrm{m}$ in diameter approximately 1500 -fold. Aliquots of this suspension $(1 \mathrm{~mL})$ were amended with the XTT reagent (XTT Cell Proliferation Assay Kit, Trevigen cat. no. $4891-025-\mathrm{K})$ to a final concentration of $330 \mu \mathrm{M}$; the electron-coupling agent (phenazine methosulfate) was not included in the assay (see Roslev and King, 1993).

Individual samples in $1.5 \mathrm{~mL}$ microcentrifuge tubes were placed in $50 \mathrm{~mL}$ conical tubes that were either transparent or covered with black electrical tape (i.e., dark incubation), affixed to a nylon tether, and incubated in the borehole at a depth of $1.5 \mathrm{~m}$ below the surface. A packer (Muni-Ball ${ }^{\circledR}$ ) was inflated $1 \mathrm{~m}$ above the samples to prevent direct light transmittance through the water in the borehole. At designated time points, formazan production was determined in triplicate samples by measuring absorption at $470 \mathrm{~nm}$ with an Ocean Optics USB4000-UV-VIS miniature spectrometer.

\subsection{Dissolved oxygen concentration and oxygen uptake rates}

The concentration of dissolved oxygen was measured using Winkler titration and the dissolved oxygen test kit (Hanna Instruments, cat. no. HI3810). To determine oxygen uptake rates, samples of the water were dispensed into $30 \mathrm{~mL}$ serum vials (Wheaton, cat. no. W223743) and sealed with butyl rub- ber stoppers while ensuring that no air bubbles were present in the headspace. During transport from the field site and shipment to the laboratory at Louisiana State University, the samples were kept chilled on blue ice and stored in the dark. A total of 2 weeks after sample collection, the serum vials were transferred to an environmental chamber, temperature probes were placed directly above the vials, and the samples were incubated at $5{ }^{\circ} \mathrm{C}$. All samples were incubated under a continuous illumination of $\sim 270 \mu \mathrm{mol}$ photons $\mathrm{m}^{2} \mathrm{~s}^{-1}$, with half of the vials covered with aluminum foil for dark incubation. Over the course of 117 days, triplicate measurements of dissolved oxygen concentration and cell abundance were made on the samples. Rates of oxygen uptake and cell growth at $5^{\circ} \mathrm{C}$ were adjusted to the in situ temperature of $0{ }^{\circ} \mathrm{C}$ using the Arrhenius equation and an energy of activation of $63 \mathrm{~kJ} \mathrm{~mol}^{-1}$ (Priscu, 2013).

\subsection{DNA extraction, amplification of $16 \mathrm{~S} / 18 \mathrm{~S}$ rRNA gene sequences, and phylogenetic analysis}

The filters obtained for nucleic acid extraction were quartered, placed in cryotubes containing a solution of $40 \mathrm{mM}$ EDTA pH 8.0 and $50 \mathrm{mM}$ Tris pH 8.3, and stored chilled in an insulated cooler on the glacier for approximately 1 week. Immediately after return from the field, sucrose was added to the storage buffer (final concentration of $0.73 \mathrm{M}$ ) and the cryotubes were frozen and shipped overnight to Louisiana State University on blue ice. The samples were stored in a laboratory freezer at $-80^{\circ} \mathrm{C}$ until analyzed.

To extract DNA from the filters, a sterile scalpel was used to cut the filter into small pieces to enhance yield during bead beating. Sterile forceps were used to transfer the filter pieces to bead beating tubes. The storage buffer remaining in the cryotubes was centrifuged at $16000 \times g$ for $10 \mathrm{~min}$ to pellet any particulates remaining in the storage buffer, and this material was added with the filter to the bead beating tubes. DNA was extracted from the samples using the Power Water DNA Isolation Kit (MO BIO Laboratories, Inc.) with the following modifications of the manufacturer's instructions. First, some of the extracted filters were separated into two bead beating tubes for the initial steps of the protocol, and subsequently the supernatants were combined on a single spin filter. Second, the samples were incubated at $65^{\circ} \mathrm{C}$ for $10 \mathrm{~min}$ after adding the lysis buffer followed by bead beating in a Mini-Beadbeater-16 (BioSpec Products Inc.) at 3450 oscillations $\min ^{-1}$ for 4 to $5 \mathrm{~min}$. Lastly, the filter was washed with an additional volume of Solution PW1, vortexed, and centrifuged and the supernatants were pooled. The genomic DNA was suspended in a $10 \mathrm{mM}$ Tris buffer, quantified by absorbance at $\mathrm{A}_{260}$ using a NanoDrop (Thermo Fisher Scientific) or a Qubit fluorometer (dsDNA HS Assay Kit, Thermo Fisher Scientific), and stored at $-20^{\circ} \mathrm{C}$. Three blank filters were included in the DNA extraction protocol to serve as procedural controls for the molecular analysis. 
A portion of the 16S rRNA gene (V4 region) was amplified from the extracted genomic DNA samples using the oligonucleotide primers 515F and 806R (Caporaso et al., 2012). Each 25 or $50 \mu \mathrm{L}$ polymerase chain reaction (PCR) contained 0.1 to $6 \mathrm{ng}$ of genomic DNA, $3 \mathrm{mM} \mathrm{MgCl}_{2}, 1 \mathrm{X}$ Gold buffer, $0.2 \mathrm{mM}$ dNTPs, $0.2 \mu \mathrm{M}$ of each primer, and 2.5 U of AmpliTaq Gold DNA polymerase LD (Invitrogen). The amplification conditions included an incubation at $95{ }^{\circ} \mathrm{C}$ for 8 to $10 \mathrm{~min}$ followed by 35 to 45 cycles of denaturation at $94{ }^{\circ} \mathrm{C}$ for $30 \mathrm{~s}$, annealing at $50^{\circ} \mathrm{C}$ for $30 \mathrm{~s}$, and extension at $72{ }^{\circ} \mathrm{C}$ for $45 \mathrm{~s}$. A final extension was performed at $72{ }^{\circ} \mathrm{C}$ for $5 \mathrm{~min}$. The amplicons were evaluated by electrophoresis through a $1 \%$ agarose gel, purified using the Mo Bio UltraClean PCR Clean-Up Kit, quantified with Qubit fluorometry, and $240 \mathrm{ng}$ of each amplicon was pooled. Paired-end sequencing was performed using the Illumina MiSeq platform (RTSF Genomics Core at Michigan State University and ICBR NextGen DNA Sequencing Core at University of Florida).

Barcodes and adapters were removed using Trimmomatic (v0.36; Bolger et al., 2014) and the amplicon sequences were processed using mothur (Schloss et al., 2009). Paired-end sequence reads of the V4 region were assembled into contigs and quality filtered using the following default parameters: maximum sequence length of 275 , minimum quality score of 25, and maximum ambiguous bases of 0 . Sequences were aligned with the mothur-compatible SILVA database (v128). Chimeric sequences were removed using the VSEARCH algorithm within mothur. The mothur-formatted Ribosomal Database Project (RDP) training set (v16) was used to assign all sequences with $\geq 97 \%$ similarity to an operational taxonomic unit (OTU). Singletons and OTUs in the procedural controls were removed before data normalization. To assess community diversity and richness of the samples, the OTU abundance data were normalized (9151 sequences); Good's estimator of coverage and Simpson's diversity index were calculated in mothur. Abundant OTUs were defined as having a relative abundance of $\geq 0.1 \%$ of the total sequences. Nonmetric multidimensional scaling (NMDS) plots were calculated within mothur and visualized in R (v.3.4.1; R Core Team, 2017).

A portion of the 18S rRNA gene (V4 and V5 regions) was amplified using genomic DNA isolated from sample BH10d and the universal eukaryal primers F566 and R1200 (Hadziavdic et al., 2014). PCRs of $25 \mu \mathrm{L}$ contained $2.8 \mathrm{ng}$ of genomic DNA, 1X Taq buffer A, $0.5 \mathrm{mM}$ dNTPs, $0.5 \mu \mathrm{M}$ of each primer, and $1.25 \mathrm{U}$ of Taq polymerase (Thermo Fisher Scientific, Inc.). The amplification protocol started with a 3 min incubation at $95^{\circ} \mathrm{C}$, followed by 35 cycles of denaturation at $95^{\circ} \mathrm{C}$ for $30 \mathrm{~s}$, annealing at $60^{\circ} \mathrm{C}$ for $45 \mathrm{~s}$, and extension at $72^{\circ} \mathrm{C}$ for $1 \mathrm{~min}$. A final extension was performed at $72^{\circ} \mathrm{C}$ for $10 \mathrm{~min}$. Gel electrophoresis through a $1 \%$ agarose gel was used to evaluate amplicon size and clone libraries were constructed with the TOPO TA Cloning Kit for Sequencing (Invitrogen) according to the manufac- turer's instructions. Individual clones (25) were cultured in Miller LB media containing $50 \mu \mathrm{g} \mathrm{mL}^{-1}$ of ampicillin, and plasmid DNA was purified using the PureLink Quick Plasmid Miniprep Kit (Invitrogen). Plasmid DNA was quantified with a NanoDrop 2000c (Thermo Scientific) and 50-150 ng of each was used to bidirectionally sequence each insert by Sanger sequencing (Eton Bioscience, Inc.).

Phylogenetic tree construction was conducted by aligning the query sequences based on secondary structure to their nearest neighbors using SINA alignment services (Pruesse et al., 2012). The sequence alignment was trimmed using MEGA7 and a phylogenetic tree was created with the maximum likelihood method (Kumar et al., 2016). Bootstrap values were calculated in MEGA7 based on Felsenstein's method and 1000 replicates.

\subsection{Statistical analysis}

The assumption of normality was evaluated using the Shapiro-Wilk test. The strength of linear and montonic correlations between geochemical and microbiological variables was assessed by evaluating Pearson's $\left(r_{\mathrm{p}}\right)$ and Spearman's $\left(r_{\mathrm{s}}\right)$ correlation coefficients, respectively. A Student's $t$-distribution test was applied to determine the probability of significant differences among variables $(\alpha \leq 0.05)$. Statistical differences among the microbial communities were evaluated using analysis of molecular variance (AMOVA) in mothur (Schloss et al., 2009).

\section{Results}

\subsection{Evidence for a porous weathering crust and near-surface aquifer system}

During the first 11 days of field work in June 2014, there was no evidence for porous flow of water into boreholes that had been drained of meltwater. However, borehole 4 (BH4; hereafter, all boreholes are similarly abbreviated as designated in Table S1) gradually filled during the final 2 days of observation and samples of the water were collected (Fig. S1) on 20 June 2014 (BH4b). From late June to early July 2015, the same location on the glacier was revisited and similar observations were made. Surface meltwater subsequently infiltrated two of the boreholes (BH8 and BH9) and only BH10 remained isolated from direct surface input; therefore, it was used as the source for the WCA water samples collected in 2015. BH10 was melted on 25 June 2015, and based on a slow initial rate of refill combined with uncertainly about the contribution of runoff from 2 days of rainfall, the water was drained after approximately 1 week and discarded. Opportunely, subsequent refill of $\mathrm{BH} 10$ on three consecutive days (5, 6, and 7 July 2015; samples BH10b, BH10c, and BH10d, respectively; Table S1) provided a total of $\sim 110 \mathrm{~L}$ of water from the WCA for analyses. 


\subsection{Physical conditions}

A one-dimensional numerical model of heat diffusion, advection, and production was used to create a prediction of temperature (Fig. 1a) and subsurface melt distribution in the ice based on internal heating (Fig. 1b). Modeled temperatures are dominated by the effects of downward propagation of the winter cold wave to depths of $\sim 10 \mathrm{~m}$ (Fig. 1a). Somewhat more subtle is the development of an isothermal, temperate summer layer in the top $\sim 2 \mathrm{~m}$ of the glacier due to internal heating caused by penetration of solar radiation. Once at the melting point, this layer experiences internal melting resulting in water contents of up to $200 \mathrm{~L} \mathrm{~m}^{-2}$ or $\sim 10 \%$ by volume (Fig. 1b). The onset of freezing air temperatures in winter quickly eliminates the water-bearing layer in the model.

Comparison of the modeled and observed temperatures (Fig. 1c) shows some similarities and some differences. In July 2015, all three temperature sensors at depths of 15,25 , and $35 \mathrm{~m}$ reported the ice to be temperate, ca. $0{ }^{\circ} \mathrm{C}$, in spite of the fact that the model predicts temperate conditions only at $35 \mathrm{~m}$ in depth. During the second half of the record, the observed ice temperatures at $15 \mathrm{~m}$ in depth drop markedly and reach less than $-1^{\circ} \mathrm{C}$ by early September. At depths of 25 and $35 \mathrm{~m}$, ice temperatures also drop but much more gradually, and by a smaller magnitude, ca. $-0.1{ }^{\circ} \mathrm{C}$. Surface observations in this ice marginal study area confirmed the presence of many crevasses and crevasse traces, as well as moulins. Hence, disagreements between modeled and observed temperatures are attributable to the fact that the former does not include such heterogeneities, which may play an important role in transporting water and heat within the ice column. The model also makes no provision for meltwater percolation and storage in intercrystalline veins. Where fast drainage pathways exist (i.e, crevasses and moulins), the meltwater table can drop well below the surface and permit air access and rapid ice cooling, as indicated by the $15 \mathrm{~m}$ sensor (Fig. 1c). Heterogeneities enabling advective transport of heat and water significantly alter the simplified picture of physical conditions in near-surface ice, tending to expand the vertical extent of temperate wet ice beyond the depth of several meters affected by penetration of solar radiation (Fig. 1a). Such heterogeneities would also enable transport of microbial cells and nutrients into deeper ice.

To examine the optical properties of the near-surface ice and its potential to support photosynthetic activity, the diel flux of incident PAR $(400-700 \mathrm{~nm})$ and PAR attenuation with ice depth were determined (Fig. 2). Based on midafternoon borehole measurements on 16 June 2014, PAR intensity decreases exponentially with ice depth (Fig. 2a) and the PAR attenuation coefficient ( $K_{\mathrm{PAR}}$; Hodson et al., 2013) is $1.5 \mathrm{~m}^{-1}$. Comparison with PAR data for benthic mats $\left(1 \mu \mathrm{mol} \mathrm{m}{ }^{-2} \mathrm{~s}^{-1}\right.$; Hawes and Schwarz, 2001) and the water column of highly shaded Antarctic lake ecosystems ( 0.43 and $0.07 \mu \mathrm{mol} \mathrm{m}{ }^{-2} \mathrm{~s}^{-1}$; Priscu et al., 1988) implied that midday
PAR fluxes could support photosynthesis to maximum depths of 5 to $7 \mathrm{~m}$ (Fig. 2b).

\subsection{Chemical composition of the near-surface ice and WCA}

A novel ice-penetrating cryobot (Stone et al., 2014, 2018) with a water sampling system (Clark et al., 2017) was used to obtain meltwater from two boreholes (BH6 and BH7; Table S1) located within $\sim 1.5 \mathrm{~m}$ of each other, and 24 samples were collected from discrete depths of between 1.4 and $8.3 \mathrm{~m}$ and filtered for chemical analysis. These data (Table S2) indicated that $\mathrm{Ca}^{2+}$ was the dominant cation (average of $56 \pm 27 \mathrm{ppb} ; \pm$ standard deviation) and strongly positively correlated $\left(r_{\mathrm{S}}>0.62, n=24, p<0.001\right)$ to subordinate $\mathrm{K}^{+}$, $\mathrm{Na}^{+}, \mathrm{Mg}^{2+}, \mathrm{Al}^{3+}$, and $\mathrm{Fe}_{(\mathrm{aq})}$ concentrations. Sulfate was the most abundant anion ( $136 \pm 28 \mathrm{ppb}$ ) followed by $\mathrm{HCO}_{3}^{-}$ (75 $\pm 78 \mathrm{ppb}$ ), the latter of which showed large variation with depth (Fig. 3a; Table S2). Nitrate and $\mathrm{Cl}^{-}$exceeded the analytical limit of detection in approximately one-quarter of the samples in the profile, averaging $81 \pm 21$ and $172 \pm 38 \mathrm{ppb}$, respectively.

Water that percolated into $\mathrm{BH} 10$ via porous flow during July 2015 had a pH of 6.2 and 6.8 and conductivity of 12 and $4 \mu \mathrm{S} \mathrm{cm}^{-1}$ (samples BH10b and BH10d, respectively), which is a similar $\mathrm{pH}$ but higher conductivity than that observed in supraglacial waters $\left(\sim 1 \mu \mathrm{S} \mathrm{cm}^{-1}\right)$. Chemical analysis of WCA sample BH10b (Table S2) indicated that in contrast to data obtained from ice melt, $\mathrm{Na}^{+}$was the dominant cation and $\mathrm{Cl}^{-}$was the dominant anion. Comparing odds ratios for each analyte indicated that six compounds were substantially enriched (4- to 170-fold; $\mathrm{Na}^{+}, \mathrm{K}^{+}, \mathrm{F}^{-}, \mathrm{Al}^{3+}, \mathrm{Fe}_{(\mathrm{aq})}$, and $\mathrm{Br}^{-}$) and five were depleted (3- to 17-fold; $\mathrm{SO}_{4}^{2-}, \mathrm{NO}_{3}^{-}$, $\mathrm{Cr}^{3+}, \mathrm{Pb}^{2+}$, and $\mathrm{Co}^{2+}$ ) in the WCA sample relative to average concentrations in ice melt from 1.4 to $8.3 \mathrm{~m}$ (Fig. 3b). The largest differences observed between the ice and WCA chemistry were with $\mathrm{F}^{-}$(170-fold enriched in the WCA), $\mathrm{Pb}^{2+}$, and $\mathrm{Co}^{2+}$ (16- and 17-fold depleted in the WCA, respectively).

\subsection{Microbial cells and biomass in the near-surface glacial ice and WCA}

The water sampling system of the cryobot was used to collect 45 discrete samples at depths between 1.4 and $11.4 \mathrm{~m}$ to estimate the abundance of microbial cells and cellular ATP (Fig. 4a). The correlation coefficient $\left(r_{\mathrm{s}}=0.38, n=45\right) \mathrm{im}-$ plied a weak positive correlation between the cell and ATP concentration data, but the correlation was not statistically significant $(p=0.066)$. Nevertheless, the cell and ATP data profile showed similar trends, with the highest concentrations of each at depths of 1.4 to $1.6 \mathrm{~m}\left(816 \pm 270\right.$ cells mL $\mathrm{mL}^{-1}$ and $\left.155 \pm 83 \mathrm{amol} \mathrm{L}^{-1}, n=5\right)$ and the lowest values observed at depths $>7.2 \mathrm{~m}$. At depths below $2 \mathrm{~m}$, there were three horizons (4.0 to $4.1,6.3$ to 6.4 , and $8.3 \mathrm{~m}$ ) where the cell and 

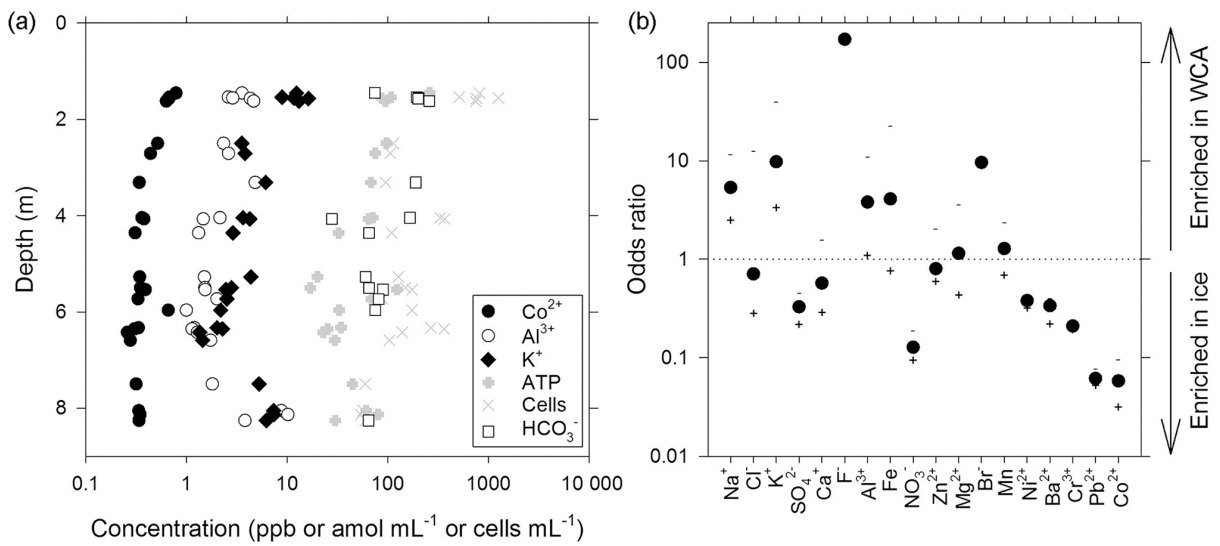

Figure 3. Geochemical composition of melted ice and water from the WCA. (a) Depth profile for analytes correlated with the cell and/or ATP data. (b) Ratio of compounds in the WCA water samples relative to the average in ice from depths of 1.4 to $11.3 \mathrm{~m}$. The order of compounds is based on their abundance in the WCA sample (i.e., decreasing abundance from left to right). The plus and minus symbols are the ratios based on the maximum and minimum values, respectively, observed in the ice profile.
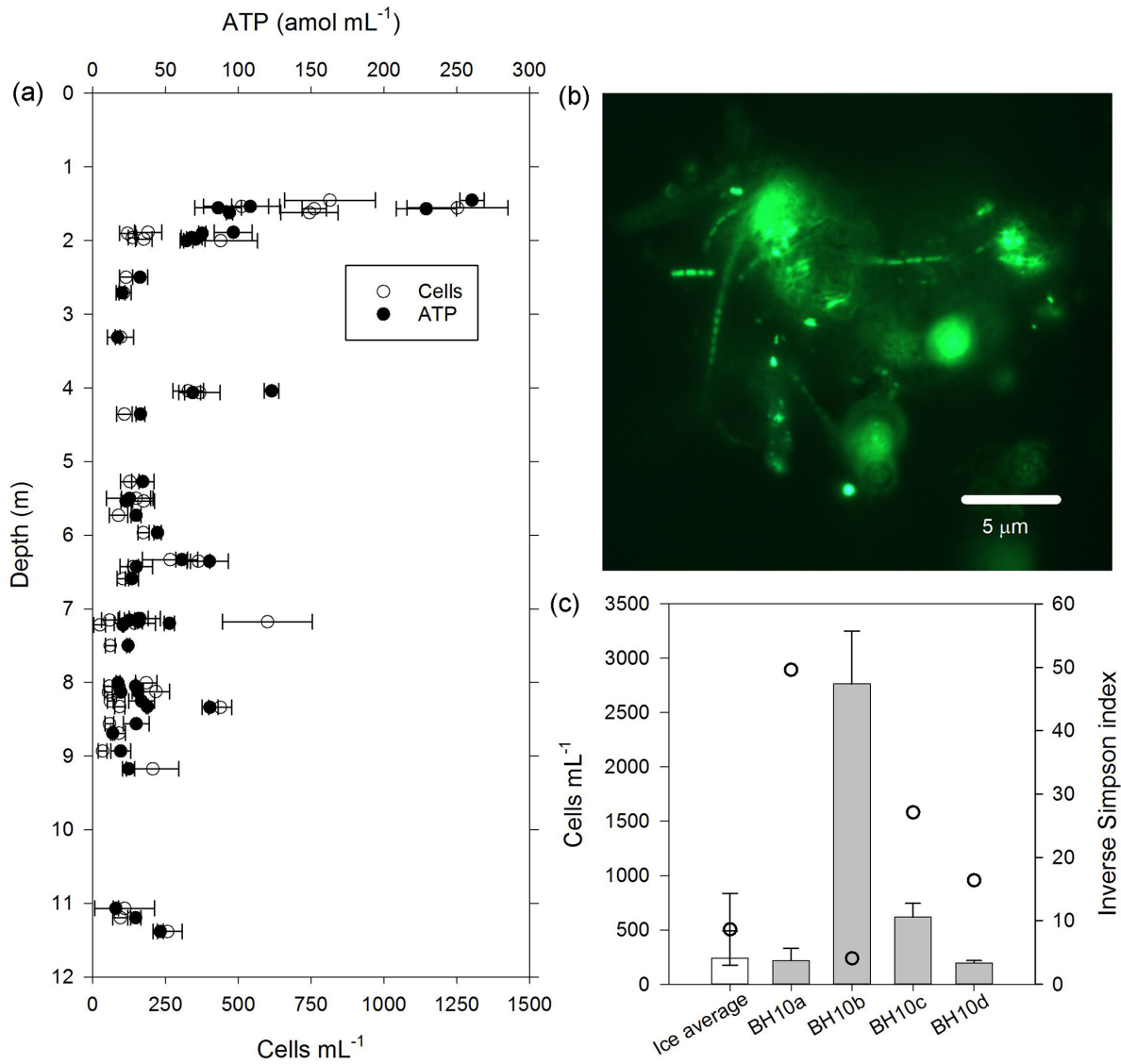

Figure 4. Cells and biomass in samples of melted ice and water from the WCA. (a) Concentration of cells and ATP from depths of 1.4 to $11.3 \mathrm{~m}$. (b) Epifluorescent micrograph showing an example of cell-particle aggregates observed in samples from the glacier's near surface (sample BH4a). (c) Comparison of community diversity (open circles) and cell concentration data from the ice (white bar) with water that percolated into the borehole (grey bars). The ice value was derived by averaging the data plotted in panel (a). The inverse Simpson index for the ice is based on average values from sampled depths between 2 and $15 \mathrm{~m}$ (BH6a, BH6b, BH6c, BH7a, BH7b, and BH7c). The error bars in panels (a) and (c) indicate the standard deviation from the mean. 

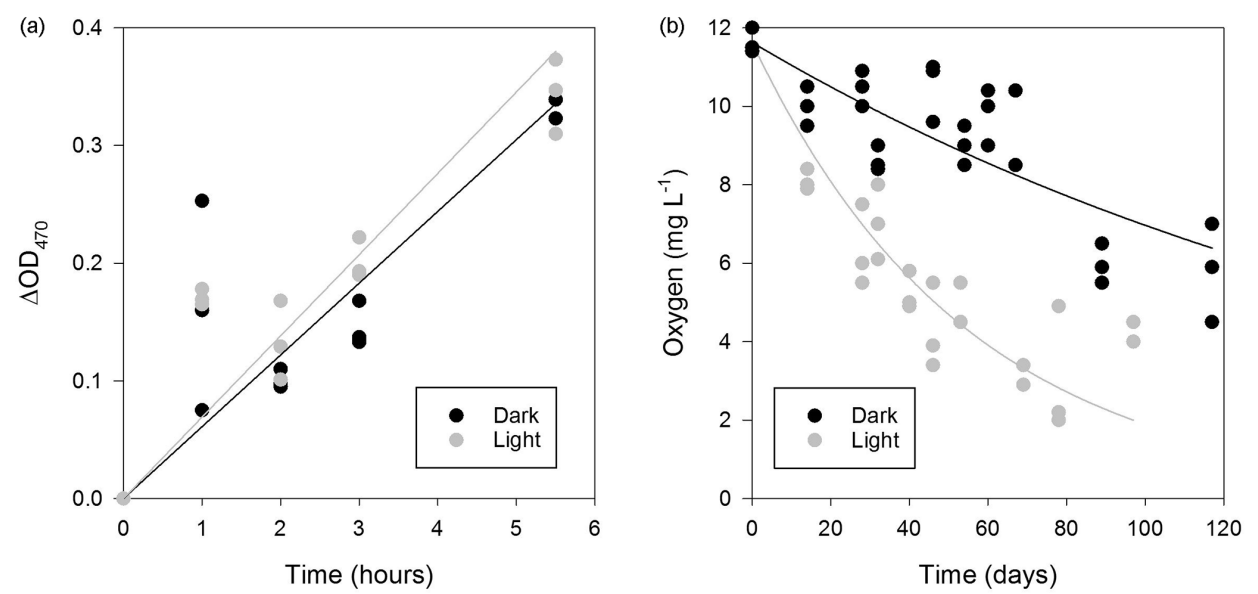

Figure 5. Respiratory activity of microorganisms in the WCA. (a) Time-dependent reduction of XTT for samples (BH5) incubated in situ. Linear regression models for the data are also plotted. (b) Oxygen consumption in the light $\left(\sim 270 \mu\right.$ mol photons $\left.\mathrm{m}^{2} \mathrm{~s}^{-1}\right)$ and dark over approximately 3 months at $5^{\circ} \mathrm{C}$ (sample BH10c). The data were fit with an exponential model (dark, $y=11.6 e^{-0.00553}, r^{2}=0.676$; light, $\left.y=11.6 e^{-0.0167}, r^{2}=0.644\right)$.

ATP concentration were higher relative to samples from adjacent depths (Fig. 4a). The cell and ATP data strongly positively correlated with $\mathrm{Co}^{2+}\left(r_{\mathrm{s}}>0.60, n=24, p<0.002\right)$ and moderately positively correlated with $\mathrm{HCO}_{3}^{-}\left(r_{\mathrm{s}}>0.47\right.$, $n=24, p<0.019)$; the ATP concentration also moderately positively correlated with $\mathrm{Al}^{3+}$ and $\mathrm{K}^{+}\left(r_{\mathrm{s}}>0.57, n=24\right.$, $p<0.004$; Fig. 3a).

The cell concentration in the water generated by melting BH10 (i.e., BH10a) was similar to average values from depths of 1.4 to $11.3 \mathrm{~m}$ (Fig. 4c) and 875-fold lower than that observed in supraglacial water $(1.92 \pm 0.465 \times$ $10^{5}$ cells $\left.\mathrm{mL}^{-1}\right)$. Relative to the second refill event collected on 5 July 2015 (BH10b; $2760 \pm 488$ cells $\mathrm{mL}^{-1}$ ), subsequent sampling on consecutive days (6 and 7 July 2015; samples BH10c and BH10d, respectively) revealed that cell concentrations in the third and fourth refills were $78 \%$ and $93 \%$ lower, respectively (Fig. 4c). The ATP concentration in water sampled from the third refill (BH10c) was $32 \pm 3.4 \mathrm{amol} \mathrm{L}^{-1}$ and slightly lower than the average for depths of 1.4 to $11.3 \mathrm{~m}$ $\left(54 \pm 50 \mathrm{amol} \mathrm{L}^{-1}\right.$; Fig. 4a).

\subsection{Microbial respiration and oxygen consumption}

The respiration potential of microorganisms in the WCA was evaluated in June 2014 by measuring the reduction of XTT [2,3-Bis(2-methoxy-4-nitro-5-sulfophenyl)-2Htetrazolium-5-carbox-anilide] during time-course experiments that were incubated at a depth of $1.5 \mathrm{~m}$ in a packered borehole. A sample for the rate measurement was obtained from water in $\mathrm{BH} 5$, which was melted 1 day prior to the experiment. To investigate if the respiration rate was affected by PAR availability at $1.5 \mathrm{~m}$ (Fig. 2), identical preparations of the samples were incubated in situ in the light and dark. Under both conditions, the production of formazan at the in situ temperature was linear over $5.5 \mathrm{~h}$ (Fig. 5a), and the slope of the data from the light $\left(b_{\text {light }}=0.0691\right)$ was slightly higher than that in the dark $\left(b_{\text {dark }}=0.0610\right)$, but formazan production was not statistically different between the treatments (Student's $t$ distribution, $p=0.46, n=29$ ).

During July 2015, water collected from the third refill event in BH10 (sample BH10c) was found to be undersaturated with respect to oxygen $\left(11.6 \pm 0.3 \mathrm{mg} \mathrm{L}^{-1}, 88 \%\right.$ of air-saturated water). To estimate the oxygen uptake rate in the WCA, the BH10c samples were sealed in serum bottles with no headspace and incubated ex situ at $5{ }^{\circ} \mathrm{C}$ in the dark and light $\left(\sim 270 \mu\right.$ mol photons $\left.\mathrm{m}^{2} \mathrm{~s}^{-1}\right)$ for 117 and 97 days, respectively. The rate of oxygen consumption during these experiments (Fig. 5b) was modeled as a first-order decay process and revealed that samples incubated in the light had a larger reaction rate coefficient $\left(k=0.0167 \mathrm{day}^{-1}, R^{2}=\right.$ $0.644)$ than those in the dark $\left(k=0.00553 \mathrm{day}^{-1}, R^{2}=\right.$ 0.676). Data from the first 32 days of incubation were used to calculate the initial rate of consumption in the light and dark (152 and $70 \mu \mathrm{g} \mathrm{O}_{2} \mathrm{~L}^{-1}$ day $^{-1}$, respectively), and the linear regression models for these conditions had significantly different slopes ( $p=0.010, n=24)$. Correction of the rate data to the in situ temperature of $0^{\circ} \mathrm{C}$ (Fig. 1a) provided oxygen consumption estimates of 42 and $92 \mu g \mathrm{O}^{2} \mathrm{~L}^{-1}$ day $^{-1}$ in the dark and light, respectively.

The WCA sample used for the ex situ incubations (BH10c) had an initial cell density of $620 \pm 130$ cells mL $\mathrm{mL}^{-1}$ (Fig. 4c). To confirm that oxygen consumption was associated with microbial growth, the cell concentration was determined approximately midway (60 and 46 days for dark and light incubations, respectively) and at the termination of the experiment. Over the time course shown in Fig. 5b, cell density increased by 3 orders of magnitude and was $6.3 \pm 0.58 \times 10^{5}$ and $5.9 \pm 0.45 \times 10^{5}$ cells $\mathrm{mL}^{-1}$ for samples incubated in the 
dark and light, respectively. Assuming exponential growth during the first half of the experiment, the mean doubling time of the populations at $0^{\circ} \mathrm{C}$ was estimated at 14 and 11 days in the dark and light, respectively.

\subsection{Composition of microbial assemblages in the near-surface ice and WCA ecosystem}

A total yield of $\leq 200 \mathrm{pg}$ (i.e., limit of detection for the DNA quantification method) to $200 \mathrm{ng}$ of genomic DNA was obtained from the filter samples extracted, a portion of which was used to amplify the V4 region of the 16S rRNA gene. Amplicons obtained from 31 samples (Table S3) and four procedural controls (three DNA extraction blanks and a PCR control, all amplified using 45 cycles) were sequenced, producing 14349197 paired-end contigs with an average read length of $253 \mathrm{bp}$. After quality filtering and removing chimeras and singletons, 10024390 sequences remained that classified as 12970 OTUs. OTUs that co-occurred in the procedural control data at abundances $>0.05 \%$ of total sequences (279 OTUs) were designated as experimental contaminants and removed from the dataset, leaving 7754705 unique reads for evaluation. Each sample was normalized to 9151 sequences, reducing the dataset to 283681 sequences that classified as 3381 OTUs. Abundant OTUs were defined as having relative abundances $\geq 0.1 \%$ of total sequences and represented between $65 \%$ and $99 \%$ of the OTUs in each sample. Based on Good's coverage estimates for the normalized sequences ( $>0.96$; Table S3), the data are sufficient to describe the most abundant taxa in the samples.

The abundant OTUs in the samples classify within nine bacterial phyla: Proteobacteria were the dominant phylum, followed by Cyanobacteria, Bacteroidetes, Actinobacteria, Armatimonadetes, Firmicutes, Acidobacteria, Deinococcus, and candidate phylum WPS-2 (eight bacterial OTUs could not be classified at the phylum level). Based on the NMDS analysis (Fig. 6a), the samples cluster into three highly significantly different groups (AMOVA; $p \leq 0.001$, $n=31$ ) that can be generally characterized as (i) 2014 samples from boreholes of 10 to $30 \mathrm{~m}$ in depth (top right of plot), (ii) 2015 samples collected at discrete depths between 2 and $15 \mathrm{~m}$ (top left), and (iii) samples heavily influenced by surface and in-ice melting (i.e., stream and WCA water; bulk ice melt from boreholes $\leq 4 \mathrm{~m}$; bottom of Fig. 6a). The vast majority of sequences in the englacial 2014 samples from borehole depths of 10 to $30 \mathrm{~m}$ were proteobacterial (94\% of the sequences), with taxa in the Actinobacteria $(3 \%)$, Bacteroidetes $(1 \%)$, Cyanobacteria (1\%), and six other phyla comprising the remainder (Fig. S2). Samples from the deepest 2015 boreholes had similar phyla distributions; however, the 2014 samples were dominated by Gammaproteobacteria, whereas betaproteobacterial OTUs were more abundant in the 2015 data. This contrasted with the assemblages in the near-surface samples, which were comprised of OTUs affiliated with the phyla Proteobac- teria (39\%), Cyanobacteria (22\%), Bacteroidetes (18\%), Actinobacteria (9\%), Armatimonadetes (2\%), Acidobacteria (1\%), Deinococcus/Thermus (1\%), and candidate phylum WPS-2 (<0.5\%; Fig. S2).

To explore the provenance of species in the glacier's near surface and ascertain if the observed distributions were consistent with the release of microbes from englacial ice during melting, an odds ratio for each OTU was calculated by comparing abundance with data from the deepest boreholes (Fig. 6b). For the 2014 samples, OTU abundances in samples $\mathrm{BH} 3, \mathrm{BH} 4 \mathrm{a}$, and $\mathrm{BH} 5$ were compared to data from $\mathrm{BH} 2(n=$ 8; Table S3). Similarly, samples from shallow 2015 boreholes (BH9 and BH10a) were compared with data from BH6, BH7, and BH8 $(n=7)$. Based on this approach, 23 OTUs in seven bacterial phyla were identified that had $>5$-fold higher abundances in the glacier's near surface (Fig. 6b) and represented approximately one-third of the sequences in these samples. Most of these OTUs classify as Alphaproteobacteria, Bacteroidetes, and Cyanobacteria, with the nearest neighbors for three of the five cyanobacterial OTUs being the 16S rRNA sequences of plastids most closely related to those possessed by chrysophyte and streptophyte algal species (Fig. S3). Several of the plastid 16S rRNA sequences were the most abundant OTUs in the near-surface samples (OTU8 and OTU9 together make up $16 \%$ of the 2014 and $11 \%$ of the 2015 data). DNA from BH10d was used to amplify and clone a portion of the 18S rRNA gene for phylogenetic analysis. Sequencing of 25 clones identified three OTUs related to green and golden algae (Fig. 6c) as well as four OTUs related to fungal, ciliate, and rotifer species (Table S4). The phylogenetic relationships of the 18S rRNA gene sequences related to members of the classes Zygnematophyceae and Chrysophyceae (Fig. 6c) were consistent with the composition of algal taxa inferred based on the plastid 16S rRNA gene data (Fig. S3).

\section{Discussion}

Near-surface internal melting of glacial ice provides liquid water for microbial metabolism and promotes meltwater percolation that can transport solutes, gases, organic matter, and cells both vertically and horizontally through a highly permeable ice layer (Irvine-Fynn et al., 2012; Cook et al., 2016). To investigate the parameters influencing the transformation of polycrystalline ice into a perched aquifer and biogeochemically active habitat during the ablation season, a one-dimensional heat conduction-production model was used to examine the effect of temperature and solar radiation on water availability in the ice. Elevated air temperatures during summer combined with heat from the dissipation of shortwave radiation produce a $\sim 2 \mathrm{~m}$ solar weathering crust that contained a meltwater fraction as high as $10 \%$ of the ice by volume (Fig. 1). The depth of meltwater production inferred by the model is consistent with observations from 


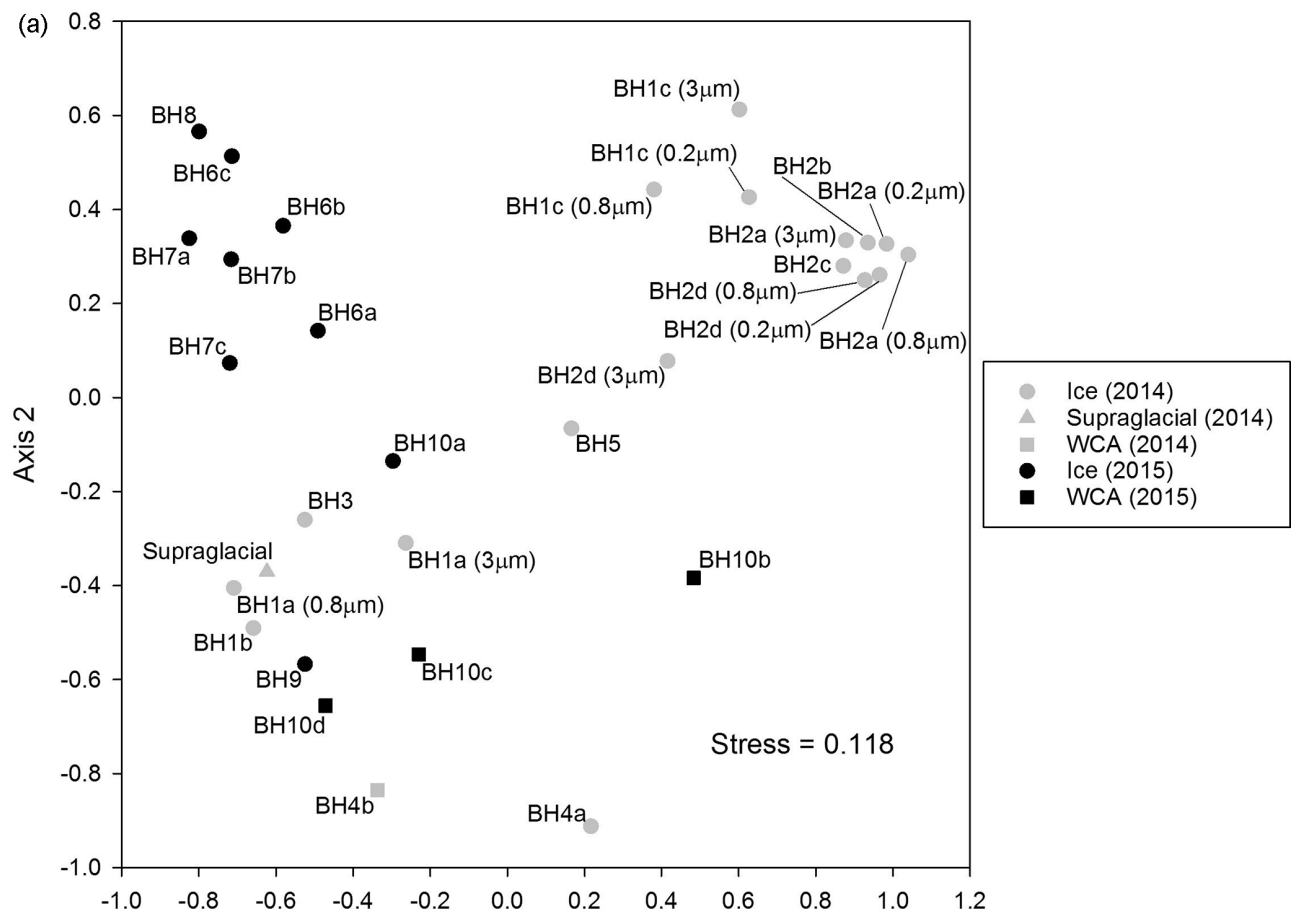

(b)

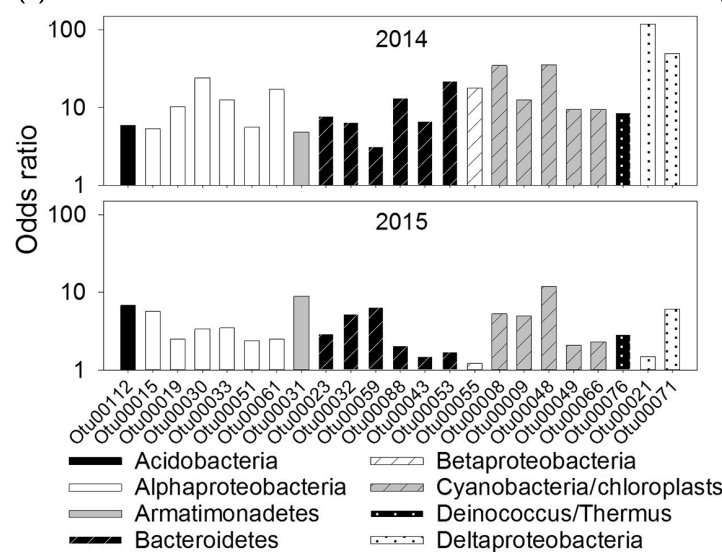

(c)

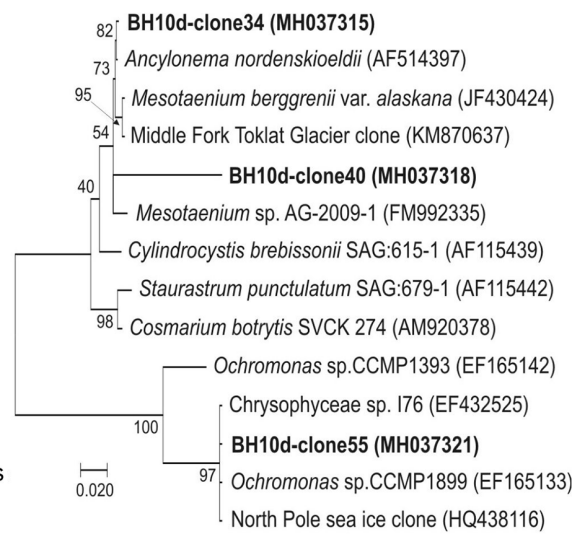

Figure 6. Microbial community structure in the ice and WCA based on analysis of 16S/18S rRNA genes. (a) NMDS ordination plot of communities observed in samples of englacial (upper left and right) and near-surface (bottom) ice. (b) Odds ratios for taxa enriched in the near-surface ice samples. The OTUs shown have abundances $>0.25 \%$ of all sequences and odds ratios $>5$-fold in samples from 2014 or 2015. (c) Phylogenetic analysis of amplified 18S rRNA gene sequences (positions 566 to 1200, Saccharomyces cerevisiae numbering) related to algae in the Zygnematophyceae and Chrysophyceae classes. GenBank accession numbers are listed in parentheses. The scale bar represents 0.020 substitutions per site and bootstrap values are shown as a percentage of 1000 replications.

High Arctic glaciers (Irvine-Fynn and Edwards, 2014) but exceeds that for Antarctic dry valley glaciers by more than 10 -fold (5-15 cm; Hoffman et al., 2014) because the ice is much colder and penetrating radiation is used to warm ice rather than melt it. Although the low-density surface ice can serve as a reservoir for $14-18 \mathrm{~cm}$ of meltwater (Cooper et al., 2018), the low hydraulic conductivities observed for Northern Hemisphere glaciers indicate that meltwater flow through the WCA is slow and inefficient (Stevens et al., 2018).
Irvine-Fynn and Edwards (2014) speculated that environmental conditions in the WCA facilitate biogeochemical processing by providing microbes with access to light, effectively extending a glacier's "photic zone" to depths beneath the surface. The PAR attenuation coefficient derived for surface ice of the Matanuska Glacier during summer 2014 $\left(K_{\mathrm{PAR}}=1.5 \mathrm{~m}^{-1}\right)$ indicates higher light propagation with depth compared to wet or dry snow $\left(K_{\mathrm{PAR}}=7.5\right.$ to $\left.20 \mathrm{~m}^{-1}\right)$ and is similar to values reported for lake, sea, and blue ice (Hodson et al., 2013, and references within). Based on 
the photosynthetic properties of highly shaded polar aquatic ecosystems (Priscu et al., 1988; Hawes and Schwarz, 2001), sufficient PAR may penetrate to ice depths of 5 to $7 \mathrm{~m}$ during daily maximums to support cyanobacterial and algal photosynthesis (Fig. 2b). However, since the solar radiation flux is incapable of producing appreciable meltwater at depths $>2 \mathrm{~m}$ (Fig. 1a), photosynthetic and microbial activity are likely localized to the near-surface region. The upper $2 \mathrm{~m}$ of ice experiences at least $3 \%$ of the surface PAR flux (Fig. 2a) and may hold up to $200 \mathrm{~L}$ of liquid water per square meter of glacier surface during the peak of the melt season (Fig. 1b). Remarkably, if the WCA community possesses species capable of acclimating to highly shaded conditions, such as those found in ice-covered Antarctic lakes $\left(0.07 \mu \mathrm{mol} \mathrm{m}^{-2} \mathrm{~s}^{-1}\right.$; Priscu et al., 1988), then the diel pattern observed during civil twilight implies the PAR flux continually exceeded the threshold necessary to support photosynthetic activity (Fig. 2b).

The oxygen uptake rate for WCA samples incubated in the light $\left(92 \mu \mathrm{g} \mathrm{O}_{2} \mathrm{~L}^{-1} \mathrm{day}^{-1}\right.$; Fig. 5b) was more than twice the values obtained in the dark $\left(42 \mu \mathrm{g} \mathrm{O}_{2} \mathrm{~L}^{-1} \mathrm{day}^{-1}\right)$ and $\sim 5$-fold lower than estimates in supraglacial melt ponds in proximity to the study site (440 to $600 \mu \mathrm{g} \mathrm{O}_{2} \mathrm{~L}^{-1}$ day ${ }^{-1}$ under ambient light; data not shown). Similar measurements in most aquatic ecosystems typically observe higher dissolved oxygen concentrations when samples are incubated in the light due to stimulation of oxygenic photosynthetic activity. Pace and Prairie (2005) and Abbasi and Chari (2008) offer four possible explanations germane to interpreting these results. First, the photochemical oxidation of inorganic or organic compounds consumes oxygen and cannot be discounted as a sink in these experiments. Nevertheless, cell growth was observed in the microcosm studies and the populations had shorter generation times in light versus dark incubations (11 and 14 days, respectively). Second, samples incubated in the light may experience higher incubation temperatures, but this possibility can be excluded because the dark samples were wrapped in aluminum foil and incubated under illumination, making uniform temperature differences among treatments unlikely. Finally, oxygen may be consumed by phototrophic algae and cyanobacteria through pseudocyclic electron transport (i.e., the Mehler reaction) or by the $\mathrm{CO}_{2}$-fixing enzyme RuBisCO (ribulose-1,5bisphosphate carboxylase/oxygenase) during photorespiration. Given the high proportion of phototrophic taxa detected in the near-surface samples (Fig. S2), these latter mechanisms provide the most plausible explanation for the elevated oxygen consumption rates during light incubation (Fig. 5b).

Meltwater production and duration in the ice are highly relevant to microbial processes in the WCA. Modeling of the ice properties under the local meteorological conditions from 2014 to 2016 suggests water content in the weathering crust increased gradually with the onset of the ablation season and that a substantial fraction of this water persisted in the ice for $\sim 7.5$ months each year (Fig. 1). Snow cover is not included in our simulations but its two main effects may cancel each other out. Snow on ice acts as a thermal insulator, decreasing the cooling effect of the winter cold wave propagating into the near-surface zone. In late spring and early summer, snow will hinder penetration of sunlight, ice warming, and generation of internal melt. Therefore, we conjecture that the two effects may impact more the timing of the beginning and the end of the seasonal WCA rather than its overall duration. Acknowledging that ex situ assays may allow microbial populations to enumerate at rates higher than those in situ (i.e., the bottle effect), the maximum generation times observed ( 2 weeks) coupled with the duration of the meltwater interval imply that 16 generations per year were possible. Assuming retention of the cells in the surface during summer (IrvineFynn et al., 2012), the potential for WCA communities to increase total biomass by 4 orders of magnitude (i.e., $2^{16}$ ) each melt season is a level of production that could significantly influence the carbon cycling budgets of ecosystems directly associated with the glacier and its drainage system (Anesio et al., 2010).

The availability of biologically labile organic carbon in WCA samples was supported by no observable lag in the time-dependent reduction of XTT to its formazan product (Fig. 5a) and also demonstrated the presence of cells with active respiratory chains and electron donors to drive oxidative phosphorylation. Elevated cell and ATP concentrations (Fig. 4a) were observed at depths with the highest predicted water contents (Fig. 1) and positively correlated with the concentration of bicarbonate (Fig. 3a), consistent with in situ microbial respiration and growth in the WCA. Several horizons below predicted depths of meltwater production showed relative increases in the concentration of cells and ATP (i.e., 4.0 to $4.1,6.3$ to 6.4 , and $8.3 \mathrm{~m}$; Fig. $4 \mathrm{a}$ ), but the microbial assemblages detected at these depths were distinctly different from those in the near-surface ice (Fig. 6a). Hence, we conclude that these represent cell populations that were deposited on the glacier's surface at a time in the past, became archived within the ice chronology, and were conveyed to the ablation zone by glacier movement. The positive correlation of the cell and ATP data with $\mathrm{Al}^{3+}$ and $\mathrm{K}^{+}$likely reflect contributions from aeolian transport to the ice surface and subsequent weathering, but the data for $\mathrm{Co}^{2+}$ (Fig. 3a) are interesting when juxtaposed with the results of Taylor and Sullivan (2008). This study showed that uptake of $\mathrm{Co}^{2+}$ and vitamin $\mathrm{B}_{12}$ synthesis by bacteria in Antarctic sea ice supplied this vital micronutrient to algae auxotrophic for $\mathrm{B}_{12}$. Consequently, the higher concentrations of $\mathrm{Co}^{2+}$ observed in the weathering crust (Fig. 3a; Table S2) could be associated with community micronutrient recycling. Interactions between phototrophic and heterotrophic guilds in this sympagic environment should be enhanced by the close proximity offered on cell-particle aggregates (Fig. 4b) and those observed shared characteristics similar to those reported in the ice covers of Antarctic dry valley lakes (Priscu et al., 1998), 
cryoconite holes (Hodson et al., 2010; Langford et al., 2010), and sea ice (Riebesell et al., 1991).

Surface water transport and emergence of ice in the actively melting ablation area are the processes most likely providing microbial inoculum to the WCA. According to NMDS ordination, microbial assemblages in the deepest boreholes (i.e., originating from englacial ice) clustered by year and were highly significantly different from samples in the glacier's near surface (Fig. 6a). Considering ablation rates of 4 to $15 \mathrm{~cm} \mathrm{day}^{-1}$ at the Matanuska Glacier during May to August (Ensminger et al., 1999; Reynolds, 2005; Mankoff and Russo, 2013), most of the ice column sampled in 2014 would have ablated by the following season (i.e., relative to the ice surface in 2014, the samples collected in 2015 originated from a deeper horizon in the glacier). Curiously, data from a $10 \mathrm{~m}$ borehole (BH1) on two consecutive days in 2014 (BH1a and $\mathrm{BH} 1 \mathrm{~b})$ clustered with near-surface ice samples, but the assemblages observed on the third day $(\mathrm{BH} 1 \mathrm{c})$ were more similar to those in the deeper 2014 boreholes (Fig. 6a). Movement of the glacier over irregular terrain has highly fractured the ice in the marginal area studied, and the hydrologically connected fracture networks of temperate glaciers link the near surface to the englacial zone (Fountain et al., 2005). The temporal changes observed in BH1 support the possibility that microbes originating from deeper portions of the ice column can be mobilized and englacially transported with water on relatively short time frames.

Microbial communities in the 2014 and 2015 samples from shallow boreholes $(4 \mathrm{~m})$, a supraglacial stream, and the WCA formed a loose cluster in NMDS ordination space (Fig. 6a). Comparison of bulk meltwater (BH4a and BH10a) with water that subsequently percolated into the boreholes (BH4b, BH10b, BH10c, and BH10d) indicated no significant difference in community structures $(p=0.138, n=6)$. The community in the first WCA sample collected in 2015 (BH10b) was considerably less diverse than that in the borehole meltwater (BH10a; Fig. 4c), plotted on the periphery of the near-surface cluster in NMDS analysis (Fig. 6a), and had a structure significantly different from the other WCA samples $(p=0.015, n=6)$. However, samples collected from BH10 over the following 2 days (BH10c and BH1Od) contained more diverse communities (Fig. 4c) that were more similar to each other and the 2014 WCA sample BH4b (Fig. 6a). Sample BH10b was collected after a period of rainfall, contained a cell concentration 5- to 14-fold higher than the other WCA samples (Fig. 4c), and was highly enriched with two gammaproteobacterial OTUs in the genera Pseudomonas and Stenotrophomonas that comprised $54 \%$ of the sequences. Together, the data from $\mathrm{BH} 10$ provide anecdotal evidence for a hydrologic response to precipitation that enhanced the mobilization of microbes from other hydrogeological regions and/or facilitated the transfer of species deposited in rain to the WCA.

If the WCA represents an ecotone between the supraglacial and englacial environment, then the presence of distinct species and community structures would be expected. However, a strict interpretation of the WCA community composition based on data from the percolating water may be complicated by the co-occurrence of microbes in the samples that originated from aquatic ecosystems on the surface, glacial ice melt, and wet or dry deposition. Odds ratios derived from sequence abundances (Fig. 6b) indicate that 23 OTUs affiliated with eight bacterial phyla and the plastids of golden and green algae (Fig. S3) were enriched more than 5-fold in the WCA relative to englacial ice samples. Four of these OTUs (OTU21, OTU31, OTU48, and OTU53) were at abundances $>1 \%$ of the sequences in the WCA and near-surface ice samples but represented $<0.1 \%$ of the sequences in supraglacial water, suggestive for the presence of distinct OTUs in the weathering crust. The largest odds ratios were observed for deltaproteobacterial OTUs in the 2014 samples, but three OTUs with high identity to plastid $16 \mathrm{~S}$ rRNA gene sequences of Zygnematophyceae and Chrysophyceae taxa (OTU8, OTU9, and OTU48) had odds ratios that ranged from 5 to 35 during both years (Fig. 6b) and represented $11 \%$ to $16 \%$ of sequences detected in the nearsurface ice samples (BH3, BH4a, BH5, BH9, and BH10a). Phylogenetic analysis of 18S rRNA gene sequences amplified from a WCA sample revealed OTUs closely related to snow and ice algae in the genera Ancylonema, Mesotaenium, and Ochromonas (Fig. 6c; Table S4). Previous studies have identified Ancylonema nordenskioldii and Mesotaenium breggrenii in Matanuska Glacier cryoconites near the terminus (Takeuchi et al., 2003) as well as on the surface of the Greenland and Antarctic ice sheets (Anesio et al., 2017; Lutz et al., 2018).

\section{Conclusions}

During the ablation season, microbes in the glacial weathering crust are provided with liquid water, solar radiation, oxygen, and conditions suitable for biogeochemical processing. Though phototrophic activity contributes new organic carbon and generates oxygen to drive heterotrophic metabolisms, primary producers and consumers in the WCA must acquire other vital nutrients to support growth, which are primarily sourced from melting glacial ice and cotransported with percolating surface water. Biomass turnover in the WCA would also mineralize and mobilize nutrients, and thus could have important roles in fertilizing supraglacial biological activity. Although the WCA of temperate glaciers can provide a liquid water oasis in the ice for over half the annual cycle, decreased solar irradiance and temperature at the onset of winter leads to freezing, entrapping the microbial community in a near-surface refuge. Hence, surviving fractions of these populations could then serve as inocula for microbial community development during the subsequent season. Since the hydrological transport of nutrient-laden meltwater may fertilize ecosystems associated with the ice surface, subglacial 
environments, and proglacial streams, elucidating the factors affecting biogeochemical flux and cycling in WCA ecosystems warrants more detailed investigation.

Data availability. The 16S rRNA gene sequence data are deposited in the National Center for Biotechnology Information's Sequence Read Archive (project number SRP130982). The cloned 18S rRNA gene sequence data are assigned the GenBank accession numbers MH037315 to MH037321 (Benson et al., 2008).

Supplement. The supplement related to this article is available online at: https://doi.org/10.5194/tc-12-3653-2018-supplement.

Author contributions. BCC, SMT, PTD, and WCS designed the research; BCC, HFL, CLD, EEO, SUN, KFM, SMT, and PTD performed the research; $\mathrm{BH}$ conducted analytical analysis; WCS developed and provided technological resources; BCC, CLD, SMT, and PTD analyzed the data; and BCC wrote the paper with contributions from all authors.

Competing interests. The authors declare that they have no conflict of interest.

Acknowledgements. This research was supported by a grant from the NASA ASTEP program (NNX11AJ89G). Partial support was also provided by the Institute of Food and Agricultural Sciences at the University of Florida. We thank Jennifer Farrar for assistance with extracting samples for nucleic acid analysis; Joseph Cook, Andrew Hodson, and John Priscu for discussion; and the two anonymous reviewers for valuable input that improved this paper. Support and assistance provided by the following 2014 and 2015 VALKYRIE field team members were crucial to the success of this research: Nathan Bramall, Evan Clark, Chris Flesher, John Harman, Bart Hogan, Josh Moor, David Rickel, Dan Sampson, Vickie Siegel, and Vicky Yuan.

Edited by: Jürg Schweizer

Reviewed by: two anonymous referees

\section{References}

Abbasi, S. A. and Chari, K. B: Environmental management of urban lakes: with special reference to Oussudu, Discovery Pub. House, New Delhi, India, 2008.

Anesio, A. M., Hodson, A. J., Fritz, A., Psenner, R., and Sattler, B.: High microbial activity on glaciers: importance to the global carbon cycle, Glob. Change Biol., 15, 955-960, https://doi.org/10.1111/j.1365-2486.2008.01758.x, 2009.

Anesio, A. M., Sattler, B., Foreman, C., Telling, J., Hodson, A., Tranter, M., and Psenner, R.: Carbon fluxes through bacterial communities on glacier surfaces, Ann. Glaciol., 51, 32-40, https://doi.org/10.3189/172756411795932092, 2010.
Anesio, A. M., Lutz, S., Christmas, N. A. M., and Benning, L. G: The microbiome of glaciers and ice sheets, NPJ Biofilms Microbiomes, 3, 10, https://doi.org/10.1038/s41522-017-0019-0, 2017.

Arcone, S. A., Lawson, D. E., and Delaney, A. J.: Shortpulse radar wavelet recovery and resolution of dielectric contrasts within englacial and basal ice of Matanuska Glacier, Alaska, USA, J. Glaciol., 41, 68-86, https://doi.org/10.3189/S0022143000017779, 1995.

Bamber, J. L. and Aspinall, W. P: An expert judgement assessment of future sea level rise from the ice sheets, Nat. Clim. Change, 3, 424-427, https://doi.org/10.1038/nclimate1778, 2013.

Benson, D. A., Karsch-Mizrachi, I., Lipman, D. J., Ostell, J., and Wheeler, D. L.: GenBank, Nucleic Acids Research, Oxford University Press, Oxford, UK, 36 (Database issue), p. D25, 2008.

Bolger, A. M., Lohse, M., and Usadel, B.: Trimmomatic: A flexible trimmer for Illumina sequence data, Bioinformatics, 30, 2114 2120, https://doi.org/10.1007/s12686-017-0754-9, 2014.

Caporaso, J. G., Lauber, C. L., Walters, W. A., Berg-Lyons, D., Huntley, J., Fierer, N., Owens, S. M., Betley, J., Fraser, L., Bauer, M., and Gormley, N.: Ultra-high-throughput microbial community analysis on the Illumina HiSeq and MiSeq platforms, ISME J., 6, 1621-1624, https://doi.org/10.1038/ismej.2012.8, 2012.

Christner, B. C., Priscu, J. C., Achberger, A. M., Barbante, C., Carter, S. P., Christianson, K., Michaud, A. B., Mikucki, J. A., Mitchell, A. C., Skidmore, M. L. Vick-Majors, T. J., and the WISSARD Science Team: A microbial ecosystem beneath the West Antarctic Ice Sheet, Nature, 512, 310-313, https://doi.org/10.1038/nature13667, 2014.

Chu, V. W.: Greenland ice sheet hydrology: a review, Prog. Phys. Geogr., 38, 19-54, https://doi.org/10.1177/0309133313507075, 2014.

Clark, E. B., Bramall, N. E., Christner, B., Flesher, C., Harman, J., Hogan, B., Lavender, H., Lelievre, S., Moor, J., Siegel, V., and Stone, W. C.: An intelligent algorithm for autonomous scientific sampling with the VALKYRIE cryobot, Int. J. Astrobiol., 17, 247-257, https://doi.org/10.1017/S1473550417000313, 2017.

Cook, J. M., Hodson, A. J., and Irvine-Fynn, T. D.: Supraglacial weathering crust dynamics inferred from cryoconite hole hydrology, Hydrol. Process., 30, 433-446, https://doi.org/10.1002/hyp.10602, 2016.

Cooper, M. G., Smith, L. C., Rennermalm, A. K., Miège, C., Pitcher, L. H., Ryan, J. C., Yang, K., and Cooley, S. W.: Meltwater storage in low-density near-surface bare ice in the Greenland ice sheet ablation zone, The Cryosphere, 12, 955-970, https://doi.org/10.5194/tc-12-955-2018, 2018.

Dee, D. P., Uppala, S. M., Simmons, A. J., Berrisford, P., Poli, P., Kobayashi, S., Andrae, U., Balmaseda, M. A., Balsamo, G., Bauer, P., Bechtold, P., Beljaars, A. C. M., van de Berg, L., Bidlot, J., Bormann, N., Delsol, C., Dragani, R., Fuentes, M., Geer, A. J., Haimberger, L., Healy, S. B., Hersbach, H., Hólm, E. V., Isaksen, L., Kållberg, P., Köhler, M., Matricardi, M., McNally, A. P., Monge-Sanz, B. M., Morcrette, J.-J., Park, B.-K., Peubey, C., de Rosnay, P., Tavolato, C., Thépaut, J.-N., and Vitart, F.: The ERA-Interim reanalysis: configuration and performance of the data assimilation system, Q. J. Roy. Meteor. Soc., 137, 553-597, https://doi.org/10.1002/qj.828, 2011.

Edwards, A. and Cameron, K. A.: Microbial life in supraglacial environments, in: Psychrophiles: From Biodiversity to Biotechnology, chap. 4, Springer, Cham, Switzerland, 2017. 
Ensminger, S. L., Evenson, E. B., Larson, G. J., Lawson, D. E., Alley, R. B., and Strasser, J. C.: Preliminary study of laminated, silt-rich debris bands: Matanuska Glacier, Alaska, USA, Ann. Glaciol., 28, 261-266, https://doi.org/10.3189/172756499781821850, 1999.

Fitzpatrick, A. A. W., Hubbard, A. L., Box, J. E., Quincey, D. J., van As, D., Mikkelsen, A. P. B., Doyle, S. H., Dow, C. F., Hasholt, B., and Jones, G. A.: A decade (2002-2012) of supraglacial lake volume estimates across Russell Glacier, West Greenland, The Cryosphere, 8, 107-121, https://doi.org/10.5194/tc-8-107-2014, 2014.

Fountain, A. G., Jacobel, R. W., Schlichting, R., and Jansson, P.: Fractures as the main pathways of water flow in temperate glaciers, Nature, 433, 618-621, https://doi.org/10.1038/nature03296, 2005.

Gardner, A. S. and Sharp, M. J.: A review of snow and ice albedo and the development of a new physically based broadband albedo parameterization, J. Geophys. Res.-Earth, 115, F01009, https://doi.org/10.1029/2009JF001444, 2010.

Hadziavdic, K., Lekang, K., Lanzen, A., Jonassen, I., Thompson, E. M., and Troedsson, C.: Characterization of the 18S rRNA gene for designing universal eukaryote specific primers, PLoS ONE, 9, e87624, https://doi.org/10.1371/journal.pone.0087624, 2014.

Hawes, I. and Schwarz, A. M.: Absorption and utilization of irradiance by cyanobacterial mats in two ice-covered Antarctic lakes with contrasting light climates, J. Phycol., 37, 5-15, https://doi.org/10.1046/j.1529-8817.1999.014012005.x, 2001.

Hodson, A., Cameron, K., Bøggild, C., Irvine-Fynn, T., Langford, H., Pearce, D., and Banwart, S.: Glacial ecosystems, Ecol. Monogr., 78, 41-67, https://doi.org/10.1890/07-0187.1, 2008.

Hodson, A., Cameron, K., Bøggild, C., Irvine-Fynn, T., Langford, H., Pearce, D., and Banwart, S.: The structure, biological activity and biogeochemistry of cryoconite aggregates upon an Arctic valley glacier: Longyearbreen, Svalbard, J. Glaciol., 56, 349362, https://doi.org/10.3189/002214310791968403, 2010.

Hodson, A., Paterson, H., Westwood, K., Cameron, K., and Laybourn-Parry, J.: A blue-ice ecosystem on the margins of the East Antarctic Ice Sheet, J. Glaciol., 59, 255-268, https://doi.org/10.3189/2013JoG12J052, 2013.

Hoffman, M. J., Fountain. A. G., and Liston, G. E.: Nearsurface internal melting: a substantial mass loss on Antarctic Dry Valley glaciers, J. Glaciol., 60, 361-374, https://doi.org/10.3189/2014JoG13J095, 2014.

Hopes, A., Thomas, D. N., and Mock, T.: Polar microalgae: functional genomics, physiology, and the environment, in: Psychrophiles: From Biodiversity to Biotechnology, chap. 14. Springer, Cham, Switzerland, 2017.

Irvine-Fynn, T. D. and Edwards, A.: A frozen asset: the potential of flow cytometry in constraining the glacial biome, Cytometry A, 85, 3-7, https://doi.org/10.1002/cyto.a.22411, 2014.

Irvine-Fynn, T. D. L., Edwards, A., Newton, S., Langford, H., Rassner, S. M., Telling, J., Anesio, A. M., and Hodson, A. J.: Microbial cell budgets of an Arctic glacier surface quantified using flow cytometry, Environ. Microbiol., 14, 2998-3012, https://doi.org/10.1111/j.1462-2920.2012.02876.x, 2012.

Karlstrom, L., Zok, A., and Manga, M.: Near-surface permeability in a supraglacial drainage basin on the Llewellyn Glacier, Juneau Icefield, British Columbia, The Cryosphere, 8, 537-546, https://doi.org/10.5194/tc-8-537-2014, 2014.
Kumar, S., Stecher, G., and Tamura, K.: MEGA7: Molecular Evolutionary Genetics Analysis version 7.0, Mol. Biol. Evol., 33, 1870-1874, https://doi.org/10.1093/molbev/msw054, 2016.

LaChapelle, E.: Errors in ablation measurements from settlement and sub-surface melting, J. Glaciol., 3, 458-467, https://doi.org/10.3189/S0022143000017202, 1959.

Langford, H., Hodson, A., Banwart, S., and Bøggild, C.: The microstructure and biogeochemistry of Arctic cryoconite granules, Ann. Glaciol., 51, 87-94, https://doi.org/10.3189/172756411795932083, 2010.

Langley, E. S., Leeson, A. A., Stokes, C. R., and Jamieson, S. S.: Seasonal evolution of supraglacial lakes on an East Antarctic outlet glacier, Geophys. Res. Lett., 43, 8563-8571, https://doi.org/10.1002/2016GL069511, 2016.

Lim, Y. I. and Jørgensen, S. B.: Distributed Dynamic Models and Computational Fluid Dynamics, in: Computer Aided Process and Product Engineering (CAPE), chap. 2, Wiley-VCH, Weinheim, Germany, 2006.

Lutz, S., McCutcheon, J., McQuaid, J. B., and Benning, L. G.: The diversity of ice algal communities on the Greenland Ice Sheet as revealed by oligotyping, Microb. Genom., 4, e000159, https://doi.org/10.1099/mgen.0.000159, 2018.

Mankoff, K. D. and Russo, T. A.: The Kinect: A low-cost, highresolution, short-range 3D camera, Earth Surf. Proc. Land., 38, 926-936, https://doi.org/10.1002/esp.3332, 2013.

Müller, F. and Keeler, C.M.: Errors in short-term ablation measurements on melting ice surfaces, J. Glaciol., 8, 91-105, https://doi.org/10.3189/S0022143000020785, 1969.

Munro, D. S.: Comparison of melt energy computations and ablatometer measurements on melting ice and snow, Arct. Alp. Res., 22, 153-162, https://doi.org/10.2307/1551300, 1990.

Munro, D. S.: Delays of supraglacial runoff from differently defined microbasin areas on the Peyto Glacier, Hydrol. Process., 25, 2983-2994, https://doi.org/10.1002/hyp.8124, 2011.

Pace, M. L. and Prairie, Y. T.: Respiration in lakes, in: Respiration in aquatic ecosystems, Oxford Univ. Press, Oxford, UK, 103-122, 2005.

Priscu, J. C.: Limnological methods for the McMurdo Long Term Ecological Research Program, available at: http://mcm.lternet.edu/sites/default/files/MCM_Limno_

Methods_AC_23_Oct_2013.pdf (last access: 12 November 2018), 2013.

Priscu, J. C., Priscu, L. R., Howard-Williams, C., and Vincent, W. F.: Diel patterns of photosynthate biosynthesis by phytoplankton in permanently ice-covered Antarctic lakes under continuous sunlight, J. Plankton. Res., 10, 333-340, https://doi.org/10.1093/plankt/10.3.333, 1988.

Priscu, J. C., Fritsen, C. H., Adams, E. E., Giovannoni, S. J., Paerl, H. W., McKay, C. P., Doran, P. T., Gordon, D. A., Lanoil, B. D., and Pinckney, J. L.: Perennial Antarctic lake ice: an oasis for life in a polar desert, Science, 280, 2095-2098, https://doi.org/10.1126/science.280.5372.2095, 1998.

Pruesse, E., Peplies, J., and Glöckner, F. O.: SINA: accurate high-throughput multiple sequence alignment of ribosomal RNA genes, Bioinformatics, 28, 1823-1829, https://doi.org/10.1093/bioinformatics/bts252, 2012.

Rassner, S. M., Anesio, A. M., Girdwood, S. E., Hell, K., Gokul, J. K., Whitworth, D. E., and Edwards, A.: Can the bacterial community of a High Arctic glacier 
surface escape viral control?, Front. Microbiol., 7, 956, https://doi.org/10.3389/fmicb.2016.00956, 2016.

R Core Team: R: A language and environment for statistical computing. R Foundation for Statistical Computing, Vienna, Austria, available at: https://www.R-project.org/ (last access: 12 November 2018), 2017.

Reynolds, H.: Evaluation of relationships between supraglacial stream discharge, ablation rates, and climate conditions at the Matanuska Glacier, Alaska, Geological Society of America, Abstracts with Programs, Boulder, CO, USA, 37, p. 84, 2005.

Riebesell, U., Schloss, I., and Smetacek, V.: Aggregation of algae released from melting sea ice: implications for seeding and sedimentation, Polar Biol., 11, 239-248, https://doi.org/10.1007/BF00238457, 1991.

Roslev, P. and King, G. M.: Application of a tetrazolium salt with a water-soluble formazan as an indicator of viability in respiring bacteria, Appl. Environ. Microbiol., 59, 2891-2896, 1993.

Schloss, P. D., Westcott, S. L., Ryabin, T., Hall, J. R., Hartmann, M., Hollister, E. B., Lesniewski, R. A., Oakley, B. B., Parks, D. H., Robinson, C. J., and Sahl, J. W.: Introducing mothur: open-source, platform-independent, communitysupported software for describing and comparing microbial communities, Appl. Environ. Microbiol., 75, 7537-7541, https://doi.org/10.1128/AEM.01541-09, 2009.

Scott, D., Hood, E., and Nassry, M.: In-stream uptake and retention of $\mathrm{C}, \mathrm{N}$ and $\mathrm{P}$ in a supraglacial stream, Ann. Glaciol., 51, 80-86, https://doi.org/10.3189/172756411795932065, 2010.

Smith, L. C., Chu, V. W., Yang, K., Gleason, C. J., Pitcher, L. H., Rennermalm, A. K., Legleiter, C. J., Behar, A. E., Overstreet, B. T., Moustafa, S. E., and Tedesco, M.: Efficient meltwater drainage through supraglacial streams and rivers on the southwest Greenland ice sheet, P. Natl. Acad. Sci. USA, 112, 10011006, https://doi.org/10.1073/pnas.1413024112, 2015.

Smith, L. C., Yang, K., Pitcher, L. H., Overstreet, B. T., Chu, V. W., Rennermalm, A. K., Ryan, J. C., Cooper, M. G., Gleason, C. J., Tedesco, M., and Jeyaratnam, J.: Direct measurements of meltwater runoff on the Greenland ice sheet surface, P. Natl. Acad. Sci. USA, 114, E10622-E10631, https://doi.org/10.1073/pnas.1707743114, 2017.

Sole, A. J., Mair, D. W. F., Nienow, P. W., Bartholomew, I. D., King, M. A., Burke, M. J., and Joughin, I.: Seasonal speedup of a Greenland marine-terminating outlet glacier forced by surface melt-induced changes in subglacial hydrology, J. Geophys. Res.-Earth, 116, F03014, https://doi.org/10.1029/2010JF001948, 2011.

Stevens, I. T., Irvine-Fynn, T. D., Porter, P. R., Cook, J. M., Edwards, A., Smart, M., Moorman, B. J., Hodson, A. J., and Mitchell, A. C.: Near-surface hydraulic conductivity of northern hemisphere glaciers, Hydrol. Process., 32, 850-865, https://doi.org/10.1002/hyp.11439, 2018.
Stibal, M., Box, J. E., Cameron, K. A., Langen, P. L., Yallop, M. L., Mottram, R. H., Khan, A. L., Molotch, N. P., Chrismas, N. A., Calì Quaglia, F., and Remias, D.: Algae drive enhanced darkening of bare ice on the Greenland ice sheet, Geophys. Res. Lett., 44, 11463-11471, https://doi.org/10.1002/2017GL075958, 2017.

Stone, W. C., Hogan, B., Siegel, V., Lelievre, S., and Flesher, C.: Progress towards an optically powered cryobot, Ann. Glaciol., 55, 1-13, https://doi.org/10.3189/2014AoG65A200, 2014.

Stone, W., Hogan, B., Siegel, V., Harman, J., Flesher, C., Clark, E., Pradhan, O., Gasiewski, A., Howe, S., and Howe, T.: Project VALKYRIE: Laser-powered cryobots and other methods for penetrating deep ice on Ocean Worlds, Outer Solar System: Prospective Energy and Material Resources, Springer, Cham, Switzerland, 47-165, https://doi.org/10.1007/978-3-319-738451_4, 2018.

Takeuchi, N., Kohshima, S., and Segawa, T.: Effect of cryoconite and snow algal communities on surface albedo on maritime glaciers in south Alaska, Bulletin of Glaciological Research, 20, 21-27, 2003.

Taylor, G. T. and Sullivan, C. W.: Vitamin B12 and cobalt cycling among diatoms and bacteria in Antarctic sea ice microbial communities, Limnol. Oceanogr., 53, 1862-1877, https://doi.org/10.4319/lo.2008.53.5.1862, 2008.

Tedstone, A. J., Bamber, J. L., Cook, J. M., Williamson, C. J., Fettweis, X., Hodson, A. J., and Tranter, M.: Dark ice dynamics of the south-west Greenland Ice Sheet, The Cryosphere, 11, 24912506, https://doi.org/10.5194/tc-11-2491-2017, 2017.

van Beusekom, A. E., O’Nell, S. R., March, R. S., Sass, L. C., and Cox, L. H.: Re-analysis of Alaskan benchmark glacier massbalance data using the index method (No. 2010-5247), US Geological Survey, available at: https://pubs.usgs.gov/sir/2010/5247/ pdf/sir20105247.pdf (last access: 12 November 2018), 2010.

Yallop, M. L., Anesio, A. M., Perkins, R. G., Cook, J., Telling, J., Fagan, D., MacFarlane, J., Stibal, M., Barker, G., Bellas, C., and Hodson, A.: Photophysiology and albedochanging potential of the ice algal community on the surface of the Greenland ice sheet, ISME J., 6, 2302-2313, https://doi.org/10.1038/ismej.2012.107, 2012.

Zawierucha, K., Kolicka, M., Takeuchi, N., and Kaczmarek, Ł.: What animals can live in cryoconite holes? A faunal review, J. Zool., 295, 159-169, https://doi.org/10.1111/jzo.12195, 2015.

Zwally, H. J., Abdalati, W., Herring, T., Larson, K., Saba, J., and Steffen, K.: Surface melt-induced acceleration of Greenland ice-sheet flow, Science, 297, 218-222, https://doi.org/10.1126/science.1072708, 2002. 